\title{
Education in Ecological Engineering-a Need Whose Time Has Come
}

\author{
Glenn Dale ${ }^{1,2}$ (D) Gabriela Dotro ${ }^{3}$. Puneet Srivastava ${ }^{4}$. David Austin ${ }^{5}$. \\ Stacy Hutchinson ${ }^{6}$ - Peter Head ${ }^{7}$ - Ashantha Goonetilleke ${ }^{8}$ - Alexandros Stefanakis ${ }^{9}$. \\ Ranka Junge ${ }^{10}$. José A. Fernández L. ${ }^{11}$ • Vanessa Weyer ${ }^{12}$. Wayne Truter $^{12}$. \\ Devi Bühler ${ }^{10} \cdot$ John Bennett ${ }^{2} \cdot$ Hongbo Liu ${ }^{13} \cdot \mathrm{Zifu}^{\mathrm{Li}}{ }^{14}$ • Jianqiang Du ${ }^{15,16}$. \\ Petra Schneider ${ }^{17}$. Jochen Hack ${ }^{18}$. Andreas Schönborn ${ }^{10}$
}

Received: 4 March 2021 / Accepted: 8 March 2021 / Published online: 12 June 2021

(C) The Author(s) 2021

\begin{abstract}
Overcoming Limitations of Ecology and Engineering in Addressing Society's Challenges By providing an integrated, systems-approach to problem-solving that incorporates ecological principles in engineering design, ecological engineering addresses, many of the limitations of Ecology and Engineering needed to work out how people and nature can beneficially coexist on planet Earth. Despite its origins in the 1950s, ecological engineering remains a niche discipline, while at the same time, there has never been a greater need to combine the rigour of engineering and science with the systems-approach of ecology for pro-active management of Earth's biodiversity and environmental life-support systems. Broad consensus on the scope and defining elements of ecological engineering and development of a globally consistent ecological engineering curriculum are key pillars to mainstream recognition of the discipline and practice of ecological engineering.

The Importance of Ecological Engineering in Society In this paper, the importance of ecological engineering education is discussed in relation to the perceived need of our society to address global challenges of sustainable development. The perceived needs of industry, practitioners, educators and students for skills in ecological engineering are also discussed.

The Importance and Need for Ecological Engineering Education The need for integrative, interdisciplinary education is discussed in relation to the scope of ecology, engineering and the unique role of ecological engineering.
\end{abstract}

Glenn Dale

glenn.dale@verterra.com.au

Andreas Schönborn

sand@zhaw.ch

Extended author information available on the last page of the article 
Scope for a Universally Recognised Curriculum in Ecological Engineering The scope for a universally recognised curriculum in ecological engineering is presented. The curriculum recognises a set of overarching principles and concepts that unite multiple application areas of ecological engineering practice. The integrative, systems-based approach of ecological engineering distinguishes it from the trend toward narrow specialisation in education. It is argued that the systems approach to conceptualising problems of design incorporating ecological principles is a central tenant of ecological engineering practice. Challenges to Wider Adoption of Ecological Engineering and Opportunities to Increase Adoption Challenges and structural barriers to wider adoption of ecological engineering principles, embedded in our society's reliance on technological solutions to environmental problems, are discussed along with opportunities to increase adoption of ecological engineering practice. It is suggested that unifying the numerous specialist activity areas and applications of ecological engineering under an umbrella encompassing a set of core principles, approaches, tools and way of thinking is required to distinguish ecological engineering from other engineering disciplines and scale up implementation of the discipline. It is concluded that these challenges can only be realised if ecological engineering moves beyond application by a relatively small band of enthusiastic practitioners, learning by doing, to the education of future cohorts of students who will become tomorrow's engineers, project managers, procurement officers and decision makers, applying principles informed by a growing body of theory and knowledge generated by an active research community, a need whose time has come, if we are to deploy all tools at our disposal toward addressing the grand challenge of creating a sustainable future.

Keywords Ecological engineering · Ecological engineering curriculum · Ecological engineering design - Nature based solutions · Sustainable development - Interdisciplinary education · Systemsbased $\cdot$ Environmental challenges

\section{Introduction}

\section{The Need for Ecological Engineering}

Working out how people and nature can beneficially coexist on planet Earth is the grandest of all society's challenges. Yet our current approaches and disciplines applied to addressing this challenge are inadequate $[1,2]$. This is evidenced by continuing decline in the health and resilience of key environmental systems, combined with the unsustainable use of nonrenewable resources and the unprecedented loss of biodiversity [3, 4, 5]. In addition, several countries report a decrease in life expectancy (USA: [6]; UK: [7]).

Recognising the need to achieve conservation and manage sustainable development, we are torn between an imperative to preserve refuges of the natural environment and engineering technical solutions that attempt to control nature. One selectively deals with parts of nature while ignoring other parts [8]. The other is frequently a shell game, moving problems from one form or location to another while giving the appearance of control [9]. A strong focus on preservation of natural ecosystems in reserves can create the notion that preserving the wild means keeping people out [8] or, conversely, conservation outside reserves is less important $[10,11]$. Similarly, engineered systems often deal with a narrow section of materiel flow cycles and are focussed on attaining development approval and meeting environmental compliance to minimise harm rather 
than exploring opportunities for environmental benefit through closed cycles. Traditional engineered systems may give the perception of control but may not be stable through time where the realities of inexorable ecological processes are not considered in design [12].

An integrated approach that considers the environment not only in wild preserves, but in our suburbs, cities and everything we do [8], combined with technology that works with, and beneficially for, nature through cycles closed as much as possible, is required if we are to truly solve the intractable problems of environmental degradation of the physical and spiritual life support system we call Earth.

Policy makers and governments around the world have recognised the urgent need to integrate ecosystems and ecological functions in land use planning and engineering design through the development of guiding concepts such as Green Infrastructures [13, 14] and Nature-based Solutions $[15,16]$. Ecological engineering comprises a disciplinary foundation and the practice to support the implementation of these concepts.

Ecological engineering has been conceived as a field that involves the design, construction, and management of sustainable ecosystems that integrate society's needs with the natural environment for the benefit of both [9]. Schönborn and Junge [17] have suggested broadening the definition of ecological engineering to incorporate the integration of ecological principles, processes and organisms with existing engineering practice into a holistic approach for problem solving.

Limitations of both ecology and engineering in addressing global challenges of sustainable development are addressed in the integrated field of ecological engineering. It also involves engineering through quantitative, performance-based approaches to designing solutions that rely on science [9]. It involves ecology through the requirement to consider the interrelationship between natural systems, processes and cycles [17], and it is a technology that builds on the self-organising nature of Earth's ecosystem or the dynamic equilibrium of controlled biological systems as well as on design inspired by ecological principles [9].

Despite its origins in the 1950s and the apparent benefits, adoption, practice and recognition of ecological engineering as an explicit discipline remains limited. At the same time, with rising global population, living standards and resource consumption, there has never been a greater need to combine the rigour of engineering with the systems approach of ecology for pro-active management of Earth's biodiversity and environmental life-support systems. The inertia to adopt ecological engineering practice may be explained, in part, by structural barriers. Engineering practice has evolved in a historic context of cheap carbon energy, abundant water resources, and open, linear material cycles. Conservation efforts and the structure of organisations charged with managing environmental health have focused on minimising impacts rather than maximising mutual benefits to society and the environment. The cognitive orientation (Weltanschauung) of ecological engineering is decarbonized energy, efficient use of water and natural resources, and closed material cycles with comprehensive integration of ecological science and engineering.

\section{Practice-Led Theory of Ecological Engineering}

By providing an integrated, systems-approach to problem-solving and incorporation of ecological principles in engineering design, ecological engineering addresses many of the limitations of ecology and engineering needed to work out how people and nature can beneficially coexist. This, in turn, requires a new paradigm in engineering education.

Ecological engineering is transdisciplinary [18], drawing upon and integrating engineering, environmental and ecological disciplines. A unifying disciplinary framework of ecology and 
engineering cannot reduce its parent disciplines into neat theoretic packages because problems must be solved in the complexity of the world. Consequently, ecological engineering will need to evolve as a set of core disciplines with common preparatory curricula in ways analogous to its parent disciplines.

A substantial catalogue of disciplines germane to ecological engineering core curricula could be compiled citing many projects and disciplinary domains that are de facto ecological engineering. Biological process engineering advances rely on sophisticated knowledge of microbial ecology [19] only partially featured in standard textbooks [20]. Highway engineering has design specifications for wildlife overpasses and underpasses. This practice unifies concepts of island biogeography, wildlife behavioural ecology and highway safety engineering $[21,22]$. Restoration ecology is a thriving and diverse discipline [23] that is a branch of ecological engineering. The same assertion is true for ecological engineering in general [18]. Common core curricula for ecological engineering can draw upon rich domains of applied ecology and de facto ecological engineering (e.g., [24]). A key task of the academy is to use these knowledge domains systematically in core curricula as ecological engineering evolves.

The term de facto ecological engineering is one of convenience. Founding theory of ecological engineering was necessarily exploratory, mapping out the potential for project applications with limited project experience. Ultimately, every engineering discipline must be grounded in the pragmatism of performance - what was the design supposed to do and did it do it? There must be quantifiable measures of success in solving problems or shaping design. A body of projects and their underlying foundations create a knowledge domain. De facto ecological engineering projects have imported ecology as needed or useful (ad hoc) to existing engineering practice or engineering methods into applied ecology.

Theory is extracted from practice. For historic context, it is worth remembering that the steam engine predates thermodynamic theory by a century $[25,26]$. Theory is essential but proceeding empirically with the knowledge at hand is even more critical for engineering. De facto is not a term of denigration, however ad hoc its development. Rather, it recognises developed branches of ecological engineering demanding close attention from academia to develop broader theoretic frameworks.

The branches of ecological engineering have evolved in relation to the problems confronted by their practitioners who needed to provide solutions. At the very least, engineers need to attain the right measure of ecological literacy or ecologists engage certain engineering methods. This is an important point. By analogy, one need not be a good writer to be a good reader. However, one needs to be a good reader to engage intellectually with those who write. A transdisciplinary field operates similarly. Technically and culturally literate conversations between diverse disciplines are indispensable to the intellectual development of ecological engineering. Training of ecological engineers entails instilling literacy across a set of disciplines combined with deeper disciplinary grounding in one or two disciplines from that set.

\section{Pathways to an Ecological Engineering Curriculum}

The success of de facto ecological engineering suggests four broad paths to curricula development:

- Developing a core degree in ecological engineering.

- Concentration of ecological engineering within a well-established engineering degree (e.g., biosystems engineering or environmental engineering). 
- Implementation of ecological engineering curricula at the post-graduate level.

- Specialization of students toward ecological engineering through a minor.

The first path is challenging considering that traditional, well-established engineering degrees (especially civil and environmental engineering) may identify overlaps and, due to entrenched silo thinking, be likely to dismiss it. This challenge can be overcome with persistent communication with of our engineering peers. Examples of such efforts have started to emerge. For example, Oregon State University has established a separate ecological engineering degree in the Biological and Ecological Engineering Department. Similarly, Zurich University of Applied Sciences (ZHAW) has delivered a specialisation in ecological engineering since 1998.

Examples for the second path include an ecological engineering concentration within the biosystem engineering degree at Auburn University, within the biological and agricultural engineering degree at the North Carolina State University and an ecosystem engineering concentration within the biosystems engineering degree at Michigan State University. This approach can potentially work at other universities that have biosystems engineering or similarly named departments and has the potential to succeed as it is much easier to implement a separate concentration than a new degree.

Given the diversity of disciplines engaged in de facto ecological engineering, many of which have established accreditation requirements, the third path of a graduate programme avoids the problems of (i) accreditation; (ii) competition with other, well-established engineering programmes; and (iii) prerequisites for non-engineering majors. This approach recognises that ecological engineering requires integration of knowledge from a wide variety of areas and application of that knowledge. It scored favourably in a survey of 31 academics and practitioners in the USA (Puneet Srivastava, pers. comm.).

The fourth path is relatively easy to structure as this is familiar to faculty and recognised by accrediting agencies. However, this presents certain challenges with regards to core curricula. The intellectual core of ecological engineering entails teaching ecology to engineers and engineering to ecologists within a transdisciplinary framework. A minor may be a vehicle to meet this need and as well as preparation for graduate school concentration in ecological engineering.

\section{The Importance of Ecological Engineering in Society}

Ecological engineering as a distinct discipline only has value if it can contribute to society's need to address the global challenge of sustainable development and can demonstrate practical applications in addressing issues not fully satisfied (or created by) conventional engineering or technological solutions. This includes applications where conventional engineering or technological solutions minimise impact but do not create environmental benefit, given the cumulative effect of many small impacts still amounts to degradation of the environment.

The value of ecological engineering to society and the environment is best illustrated by real-world applications that embody its key defining elements: integrated multidisciplinary systems thinking, quantitative (often probabilistic) design applied to ecological systems and the importance of delivering performance reliability. Examples from around the globe are discussed below. 


\section{An Australian Perspective-Beneficial Use of Coal Seam Gas Water}

Gas is widely seen as a transition fuel between coal and renewables, sustaining the capacity of economies to invest in research and infrastructure necessary to move toward a fully renewable electricity grid [27]. In the year 2000, the Queensland Government in Australia introduced a scheme that required $13 \%$ of all power supplied to the state electricity grid to be generated by gas by 2005. This unleashed a wave of over AUD\$70 billion in investment in three liquefied natural gas projects [28].

However, extraction of mildly saline and highly sodic water is an integral and inseparable part of Coal Seam Gas (CSG) operations, and development of CSG reserves is contingent on the capacity to manage the 'associated' water in arid inland areas where the reserves predominate.

The average volume of associated water extracted from Queensland coal seams is estimated at $60 \mathrm{GL} / \mathrm{year}$ or $1700 \mathrm{GL}$ over the life of the reserves [29], equivalent to around 3.4 times the volume of Sydney Harbour. The required attributes of any solution to manage this volume of associated water include: (i) the capacity to operate at scale; (ii) reliability to ensure capacity to support uninterrupted gas production; (iii) flexibility to accommodate fluctuations in water production volume and quality; (iv) sustainability - a threshold requirement for all options; (v) commerciality - the need to minimise costs and risks and maximise returns within the constraints of the other attributes; and (vi) capacity to leverage community and social benefits.

In the early years of the CSG gas boom in southern Queensland, the baseline approach to managing associated water reflected the legacy approach of mine water management by impounding water in evaporation ponds. This was reinforced by legislation that restricted movement or release of water off-tenement.

As the industry began to develop, it quickly became evident that the volumes of associated water produced in CSG extraction would be impractical to manage by evaporation. In addition, the public saw this as the waste of a resource with the potential to create a long-term environmental liability requiring the removal of salt from the environment and rehabilitation of evaporation ponds at the end of their life.

From 2009 onwards, the 'grey engineering' solution of desalination by reverse osmosis (RO) rapidly evolved as the treatment method of choice. Desalination substantially expands the opportunities for beneficial use of CSG water but creates a new legacy issue in the management of concentrated brine. Desalination is financially expensive in the total cost of water treatment and waste/brine management, and highly energy intensive. While desalination achieves a high-quality water product, the approach tends to ignore consideration of water treatment to a quality that is fit-for-purpose.

In 2007, the Australian gas company, Santos, commenced a programme to investigate options for beneficial use of CSG water for irrigation of both plantation forestry and fodder crops [30]. The programme combined fit-for-purpose treatment of CSG water with flow weighted salinities of 2500 to $3200 \mu \mathrm{S} / \mathrm{cm}$. A feasibility-design study undertook water chemistry modelling combined with empirical analysis and testing of the threshold electrolyte concentration for a variety of target soils. This showed that chemical amendment of some influent CSG waters (approximately $3200 \mu \mathrm{S} / \mathrm{cm}$ ) with sulphuric acid and micronised gypsum would reduce the water sodicity and bicarbonate to levels to enable irrigation of amended CSG without impacting soil permeability and structural integrity. The design study also undertook plant water balance modelling to determine the range of irrigation loadings that could be reliably maintained given the seasonal variation in rainfall and evaporation, tree growth 
modelling, salt modelling to understand both daily variation and long-term equilibrium rootzone salinity, and hydro-geological modelling to understand the interaction of run-off and deep drainage with surface and groundwater systems.

Resulting from this study, a $10 \mathrm{ML} /$ day chemical water treatment plant was constructed to produce agricultural grade water with no waste product (i.e., $100 \%$ CSG water reuse). The chemically amended water was used to establish and irrigate over 1100ha of drip-irrigated Eucalypts argophloia forest plantation. The growth progression over time of drip-irrigated E. argophloia is illustrated in Fig. 1. Intensive monitoring of soil conditions has demonstrated alignment to modelled behaviour. Monitoring of ephemeral and perennial streams has demonstrated nil impact on riparian system water quality or flow [30].

In addition to managing water, the plantations are now registered as a carbon sequestration project under Australia's Carbon Farming Initiative and will sequester approximately 12 to $26 \mathrm{t} / \mathrm{ha} /$ year of $\mathrm{CO}_{2} \mathrm{e}$ or approximately $462,000 \mathrm{t}$ of $\mathrm{CO}_{2} \mathrm{e}$ over a 30 -year period. Notwithstanding, this is a small proportion of the emissions generated from gas combustion and demonstrates the wider global challenge of greenhouse gas abatement.

The plantations also provide forest connectivity between previously isolated remnant vegetation, contribute to conservation of Eucalyptus argophloia (a naturally restricted endemic forest tree species), and can be managed as an ongoing renewable dryland timber resource beyond the end of coal seam gas operations. Semi-quantitative analysis using the Five Capitals Sustainable Development Framework [31] indicates that appropriately implemented CSG water beneficial use programmes can contribute to an improvement in the sustainable development balance sheet of CSG developers through improvements to financial, manufactured, social, human and natural capital [32].

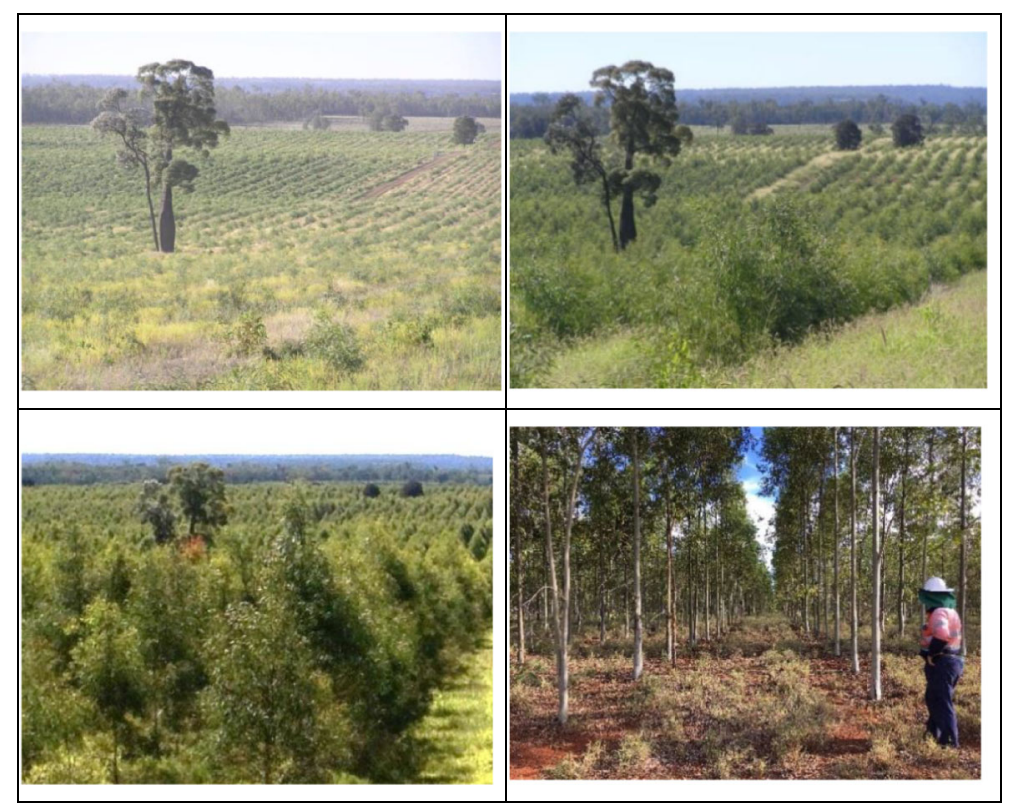

Fig. 1 Eucalyptus argophloia drip-irrigated with chemically amended CSG water: September 2009, 10 months after planting (top left); April 2010, 17 months (1.4 years) after planting (top right); April 2012, 41 months (3.4 years) after planting (bottom left); March 2017, 100 months (8.3 years) after planting (bottom right). Note that the emergent Bottle tree is barely visible in the 41-month image 
Performance reliability of the system is critical, with the $10 \mathrm{ML} /$ day forest irrigation system supporting gas production from around 500 wells producing gas with a value of approximately US $\$ 1.3 \mathrm{~m} /$ day based on the current gas production statistics [33].

By taking a holistic approach to water cycle and landscape management, this ecological engineering approach to management of coal seam gas water has created economic and environmental value from what was previously considered a waste-water resource, with lower capital and operating expense (CAPEX and OPEX) than the alternative of desalination [30]. It has avoided generation of a concentrated waste brine stream produced by reverse osmosisthe secondary effect or shell game of the 'grey engineering' reverse osmosis solution [9]. In addition to sequestration of approximately $15,400 t /$ year of $\mathrm{CO}_{2} \mathrm{e}$, the approach avoids emissions of 19,000 $\mathrm{t} \mathrm{CO}_{2} \mathrm{e} /$ year associated with the energy requirements of reverse osmosis, again, a small but symbolic contribution against the emissions from gas combustion.

\section{A European Perspective-Closing the Loops}

Europe has a long history with ecosystems and landscapes shaped by humans. Impacts of deforestation have been documented, e.g., from ancient Greek and Italian times [34], from Scotland [35], Switzerland [36] and many other places. Early mining for metals in Europe dates to the late prehistoric period, starting with copper mining [37] and continuing until today, e.g., in the open-pit mines for brown coal in Germany and Poland. The industrial development since the early 1800 s, inappropriate hazardous waste management, intensive agriculture and other human activities led to polluted soils and groundwater at various places in Europe [38].

Land consumption and scarcity is a major challenge in today's Europe. Its growing, densely populated regions import vast amounts of resources and export vast amounts of waste, thereby causing an environmental impact that needs to be compensated. In contrast, in many rural European regions, the demographic and the economic development is shrinking. This leads to the challenge that conventional grey infrastructure (e.g., water and wastewater treatment plants, pipelines, reservoirs) can no longer be operated in an economically feasible way. Examples are discussed below and illustrated in Fig. 2.

In this context, ecological engineering in Europe needs to deal with the sustainable design and operation of ecology-inspired systems that are strongly influenced and controlled by humans. The spatial scale of these systems may range from metres to hundreds of kilometres. Their functions may either build on ecosystems, or on elements of them, or even be completely technical. The common denominators are: (i) the idea of 'closing and greening the loop', following the model of mature ecosystems; (ii) the use of biological elements and ecological processes; (iii) the aim to achieve a benefit for both nature and the human society; and (iv) respecting the carrying capacity of the designed system by avoidance of pollution.

Ecological engineering as a discipline in Europe started in the late 1980s. The first book on fundamentals of 'Ingenieurökologie' in German language was issued in 1989 [39]. The International Ecological Engineering Society IEES was founded 1993 in Utrecht, The Netherlands. From the early days, there has been a variety of approaches to this field depending on the academic discipline of the proponents and on the specific situation in the country. Three early landmark conferences at Stensund, Sweden [40], Östersund, Sweden [41] and Wädenswil, Switzerland [42] showed the large variety of topics, including, e.g., constructed wetlands; wastewater-based food production; recirculating systems; decentralised source-separating sanitation; ecocities; ecological architecture; biofuel production from wastes; 


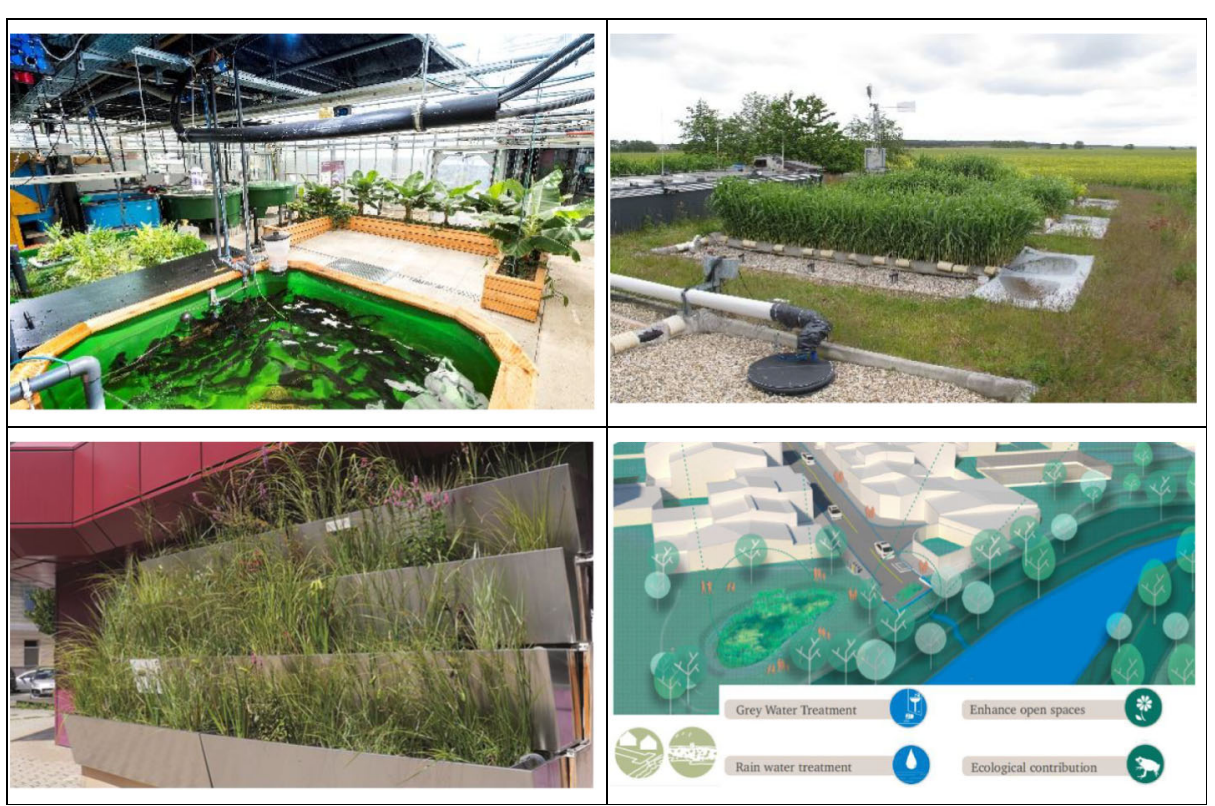

Fig. 2 Recirculating aquaponic and aquaculture facility at ZHAW Waedenswil, Switzerland (top left, photo ZHAW). Langenreichenbach Ecotechnology Research Facility (Germany) (top right, photo A. Schoenborn). vertEco green wall at Kempelenpark, Vienna (bottom left, Ines Kantauer/alchemia-nova GmbH). Green infrastructure in Darmstadt, Germany (bottom right, Jochen Hack)

urban ecosystem management; ecological measures in agricultural areas; ecosystem restoration; and even ecosystem-friendly civil engineering works and practices.

Constructed wetlands are regarded 'as established ecotechnologies to treat water pollution' [43]. Many 10,000s are in operation in Europe today for urban wastewater [44, 45] as well as for industrial wastewater [46]. Apart from these, the following developments are worth notifying:

From wastewater-based food production to recirculating systems: Initial research on wastewater-fed aquaculture was conducted, e.g., in Sweden, Denmark and Switzerland, and developed into the general research on recirculating systems, such as: (i) recirculating fish and plant culture [47]; (ii) greywater recycling [48]; and (iii) natural swimming ponds and other cyclic processes.

Decentralised and source-separating sanitation research was started in 1990s in several European countries in parallel. While 'developing' countries and simple technologies were the main focus at the beginning, today, development is focused on highly sophisticated sourceseparation, decentralised, reuse-oriented sanitation systems, such as the EU H2020 Run4Life project (https://run4life-project.eu/) or the Hamburg Water Cycle (https://www. hamburgwatercycle.de/en/home/).

Eco-cities and ecological architecture have been developing under several labels in European countries. While at the beginning, renewable energy production for heating and electricity was the main focus, recently, a more holistic trend can be observed. The current European COST Action Circular City CA17133 states that 'Transforming today's cities into sustainable cities is one of the main adaptations that will be necessary. A holistic approach looking at cities from a system's perspective is needed to achieve this goal' (https://circularcity.eu/). Apart from solar energy, biofuel generation from food or other organic wastes contributes to the energy supply. Green roofs have become a standard option for new 
developments. Green walls may become the next big innovation and may be combined with greywater treatment or even with food production.

Urban ecosystem management, focusing on combining the enhancement of biodiversity in cities with functional components such as the sponge city approach [49], is becoming popular in European cities, driven by the need to adapt to expected higher temperatures and drier summers. As a strategically planned network of natural and semi-natural areas with other environmental features designed and managed to deliver a wide range of ecosystem services, green infrastructure has become a central ecological engineering concept in Europe [50], especially in the context of reducing habitat fragmentation. While in the USA, the concept is mainly focused on urban areas, the European definition also includes ecological measures in agricultural areas to reduce evapotranspiration, erosion and nutrient loss, while enhancing biodiversity and restoring ecosystem value and water quality of the receiving inland waters, coastal wetlands and coastal waters. Besides the strategic network character, the concept of multi-functionality is a key property to unlock the potential of ecosystem services in a world of scarce resources.

The European Commission has been fostering ecological engineering approaches in their policies, particularly through the green infrastructure approach in the Biodiversity Directive of 2011 [51]. Even though ecological engineering is much more than green infrastructure, this new policy direction has supported the wider understanding of ecological engineering practices to foster sustainability strategies. These strategies have recently culminated in the new European Union Biodiversity Strategy for 2030 'Bringing nature back into our lives' [52] and the so-called Green Deal [53], a sustainability policy strategy with an ecosystem focus for the European Union. These developments, bound together in the approach of ecological engineering, may be the decisive step necessary for truly sustainable development.

\section{A North American Perspective-The Dominance of Wetlands}

North American ecological engineering practice has been dominated by treatment wetlands [54-56], lake and reservoir restoration [57], restoration ecology [23], and phytoremediation [58] as represented by textbooks in each practice domain. Notably, the textbooks cited tend not to self-identify as ecological engineering, but all clearly are. Rather than presenting a wetland case study, this section surveys the North America experience in terms of ecological engineering practice from the perspective of design practice.

The treatment wetland textbooks authored or co-authored by Robert Kadlec [54-56] represent mature ecological engineering design practice in the US. The orientation of these texts implicitly assumes formal training in environmental process engineering and wetland ecology and they most comprehensively document the North American experience of large treatment marshes (surface flow wetlands).

Although there are many thousands of media-based treatment wetlands operating worldwide (e.g., reed beds, subsurface flow), their total area is tiny compared to treatment marshes in North America. The largest treatment marsh wetland complex in the world is the stormwater treatment areas of southern Florida USA (Fig. 3). Designed to remove phosphorus, their total area is over 29,000 ha, treating an average flow of 4,400,000 $\mathrm{m}^{3} /$ day. Including research, the cost of these wetlands was US \$1 billion. Other individual North American marsh treatment wetlands range up to 500 ha in area. As of 2017, 295 treatment marshes reported data on phosphorus removal. While treatment marshes have flows well over $1000 \mathrm{~m}^{3} / \mathrm{day}$, almost all media-based wetlands treat far smaller flows in footprints of much less than 1 ha. Treatment 


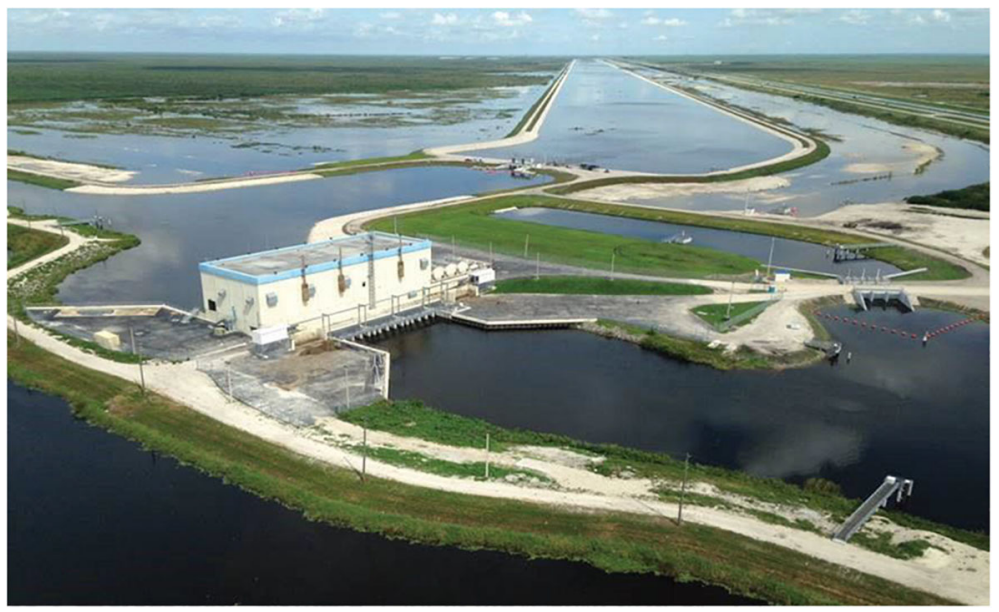

Fig. 3 A flow equalisation basin (FEB) designed to temporarily capture and hold stormwater runoff for release to the Florida Everglades stormwater treatment areas (STAs). By tempering flow rate, FEBs help maintain desired water levels in the STA and assist in optimising performance of stormwater treatment areas in removing phosphorus [59]

marshes are distributed across the entire continent, including the Arctic. The ecology of natural wetlands in all locations strongly influences their design and operation.

The accumulation of treatment marsh project experience and performance data over the past 40 years has created a mature branch of ecological engineering. Design practice itself is grounded in core disciplines of wetland ecology, hydraulics, hydrology, geochemistry, process engineering, environmental microbiology, civil engineering, botany and zoology. Some of these wetlands are in urban settings with designs that involve landscape architecture and urban planning. Although nobody is, or can be, a master of all these design sub-disciplines, mastery of wetland design entails a substantial measure of transdisciplinary literacy regardless of one's original disciplinary foundations. No design is successful without skilled attention to hydraulics, hydrology and process modelling.

There is both divergence and convergence of environmental engineering and classic ecological engineering design methods for treatment marshes. Successful designs unequivocally employ unit process methods that are critical elements within holistic designs. This point is essential because it corrects early ecological engineering concepts that unit process theory belongs to environmental and not ecological engineering. Self-organisation of wetland flora and fauna communities is fundamental yet must be managed by forcing functions which are at least partially controlled by design, with hydrology foremost among them.

The ecological context of any proposed treatment marsh is fundamental to design. The context may be climate. It may be regional variance in geochemistry. The effect of invasive species or population dynamics of native herbivores may be another context, but scale is always a context. Treatment marshes are large. A process that appears to work in mesocosm may encounter issues inherent to large scale. For example, submerged aquatic vegetation (SAV) in small test plots has been demonstrated to more effectively remove phosphorus from water compared to emergent aquatic vegetation (EAV) [60]. The mechanism is SAV photosynthetic elevation of $\mathrm{pH}$ in hard water (geochemical context) causing precipitation of carbonate phosphate complexes which is an irreversible process at elevated and circumneutral $\mathrm{pH}$. However, extreme weather events destroy SAV in large water bodies [61]. Recovery from 
dryout - a real-world problem in stormwater treatment - is much more rapid in EAV than SAV wetlands [62]. Thus, scale may make SAV treatment systems comparatively fragile ecosystems compared to treatment marshes (EAV). Overall, the ecological context of treatment marshes is nuanced and impacts design outcomes. General design theory may not capture these contexts.

Beyond the 'hard' ecological engineering aspects of treatment marshes lay society and interactions with regional ecology. Birdwatching is spectacular. Alligators take up residence. Bobcats prowl berms. Because all treatment marshes concentrate nutrients, primary productivity is exceptionally high providing food bases that extend beyond marsh boundaries. The unusually intimate access to wetland habitats provided by boardwalks in treatment marshes are so popular with the public that large parking lots are key design features. These connections to society and nature merit closer academic attention than is currently received.

Treatment wetlands are an outstanding example of ecological engineering and provide a good example of ecological engineering because of the basic elements of energy flows and system design for optimal function, resulting in design outcomes that will differ from that provided by ecology or civil engineering in isolation. Nevertheless, the branch of treatment wetland design must not be mistaken for the whole tree of ecological engineering. Other branches occupy different knowledge domains. Some overlap, others do not. There are lessons to learn from the success, maturity and dynamism of the wetland branch when considering how to orient students to the larger field of ecological engineering:

- Ecological engineering design is as reductive as it is holistic because it is transdisciplinary.

- Powerful design frameworks emerge slowly from project experience-brick by brick if you will — with key insights delivered as new disciplines are integrated into practice.

- The importance of science is hard to overstate. Because ecological engineering is, indeed, the 'acid test' of our knowledge of ecology, development of practice entails both empirical skill sets and awareness of the theoretic potential emerging from performance data.

- The art of design is just as important as science. The purpose of engineering is designs that do something supported by society and held to quantifiable performance criteria. Mastery of design is won by doing design.

- Holistic design entails a systematic synthesis of science and design art.

This summary is a provisional disciplinary meta-narrative or meta-context of the success of large marsh wetland projects in North America. As meta-narratives are extracted from other de facto branches of ecological engineering the intersection of those narratives will prove useful to structuring ecological engineering education.

\section{A Latin American Perspective-'Water Sowing' as Ecological Engineering: Water Management and Water Recharge in Lima, Peru}

Today, the water supply for Lima is at a critical point. The city expects an increase of $25 \%$ in its water demand and a rainfall decrease during the next 20 years making it harder to maintain or fill reservoir levels $[63,64]$. During the last century, Lima has developed its water supply system by transforming surrounding natural environments into large hydraulic grey infrastructures (i.e., transfer schemes, dams, irrigation channels) [65, 66]. This approach has been necessary to provide a constant water supply and allow social and economic development in the city. However, the current situation has highlighted the rigidity and low resilience of dams 
Fig. 4 Leakage in the Amuna Shucuni highlights the contrast in vegetation growth of the 'Water Sowing' technique before and after implementation

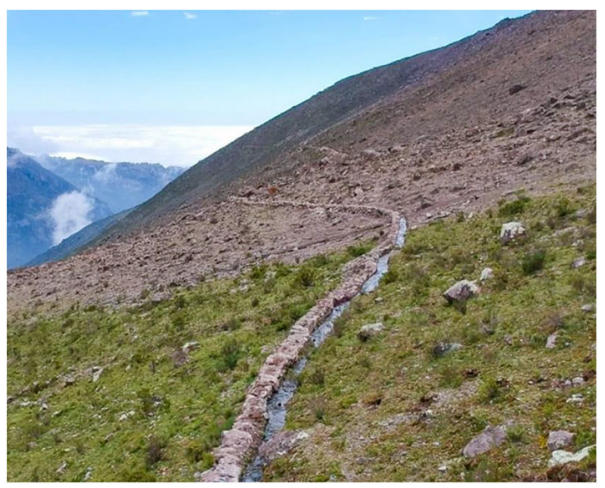

as the primary means of water supply, and the attention has shifted to ecosystem-based catchment dynamics, especially in the higher reaches.

This shift was facilitated by the adoption of an integrated water resources management (IWRM) framework in 2009 that encouraged a continuous process of change in the design of future water supply systems. In 2015, the National Superintendence of Sanitation Services (SUNASS) established a fund to pay for ecosystem services to allow the water utility for Lima, SEDAPAL ${ }^{1}$, to implement projects that contribute to catchment recovery [67]. Since implementation of this innovative approach, SEDAPAL has relied on NGOs and communities to identify projects that consider local ecology and ecosystem services in their design. It was determined essential to work with local communities - the custodians of historical, geographically adapted knowledge of local water management practices.

In Lima's upper catchments, these practices are known as 'Water Sowing' (Siembra de Agua in Spanish). The concept refers to the practice of storing and inducing infiltration of water through restoring and building ancient hydraulic infrastructure, which are simple engineering works that have been used since pre-Inca times [68]. There are several practices of Water Sowing, however, two stand out: the rehabilitation of Amunas and the construction of artisan reservoirs (enlarged ponds).

The term 'Amunas', derived from the Quechua language, consists of a semi-permeable infiltration canal built to derive water from a waterway and make it run along a steep mountain contour. They are built with local material (rocks and dirt) and are designed with a slight slope to slow down the water flow and extend the duration of moist soils, promoting vegetation growth along the channel in the early months of the dry season (Fig. 4). The Amuna induce and stimulate infiltration. Preliminary results suggest that Amunas can, on average, increase dry season flows by $7.5 \%$ [69].

Artisan reservoirs are another structure of the Water Sowing technique. These involve construction of small dikes in nonpermeable surfaces built with local materials and designed with an engineering approach whilst considering local knowledge (Fig. 5). The construction of these artisan dike enlarges natural ponds, allowing them to store more water. Communities like San Pedro de Casta in Lima maintain records of the historical water levels in natural embankments to inform design of the dikes.

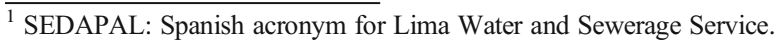




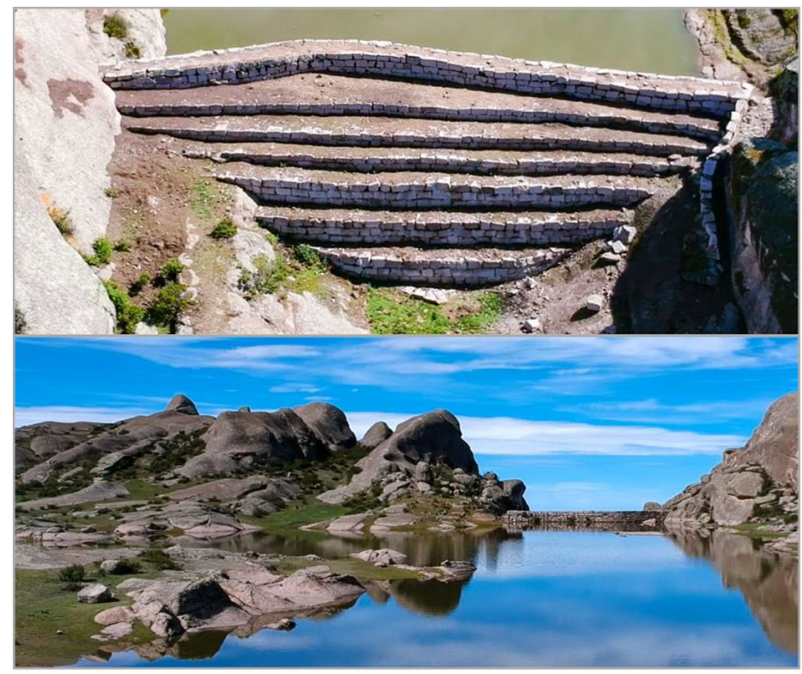

Fig. 5 Dike built of the Cachu-Cachu lake artisan reservoir: At the top of the front view and at the bottom of the rear view of the dike and the Cachu-Cachu pond

As of today, the communities supported by NGOs have recovered at least $15 \mathrm{~km}$ of Amunas and 5 artisanal reservoirs within the four catchments that provide water to Lima. These traditional practices of water management in Peru have proven to be more cost-efficient in achieving water storage (as recharge) and regulation (delayed runoff) compared to conventional grey infrastructure [71].

SEDAPAL has adopted and included the Water Sowing concept in the design of at least 25 ecosystem-based projects, however, it has not been able to implement any [72]. Public investment into ecosystem services was not allowed until 2017 when the Ministry of Economy (MEF) developed the category of 'natural infrastructure' within the public investment framework [73]. Since adoption of the IWRM approach, and despite supporting mechanisms, there is still no clear effective public investment in ecosystem services within the management of Lima's water supply.

Water Sowing is an exemplary case of ancient and geographically adapted ecological engineering that has the potential to help restore the 'bodily functions' of the catchments on which Lima depends.

\section{An Asian Perspective-A Demonstration Incorporating Ecological Engineering and Ecological Education in a Wastewater Treatment Wetland, Changsu, China}

Nature-based solutions for water resource management such as lagoon and constructed wetland technologies have been developed since the 1980s. Since the 2000 s, more and more nature-based solutions have been practically implemented. Recently, constructed wetland technologies have been widely applied in the rainwater sponge city projects, urban black odour water treatment, advanced treatment of wastewater treatment plant effluent and numerous other applications.

Treatment of wastewater from industrial parks is a worldwide challenge [74]. Changshu Advanced Materials Industrial Park (CAMIP) focuses on the development 
of new materials, fluorine chemicals, fine chemicals and biomedicine, with more than 30 chemical companies in the park [75]. The wastewater from these chemical companies is discharged into the wastewater treatment plant in the CAMIP. The treated wastewater (tailwater) meets level A of the Discharge Standard of Pollutants for Municipal WasteWater Treatment plants in China (COD: 50mg/L; NH4+-N: 5mg/L $\left(8 \mathrm{mg} / \mathrm{L}\right.$ when $\left.\mathrm{T} \leq 12^{\circ} \mathrm{C}\right)$; $\left.\mathrm{TP}: 0.5 \mathrm{mg} / \mathrm{L}\right)$. However, because the outlet of this tailwater is at the junction of the Yangtze River and the Wangyu River flowing into the Tai Lake, the local government hopes to improve the tailwater quality to the Level IV Surface Water Standard (COD: $30 \mathrm{mg} / \mathrm{L} ; \mathrm{NH}_{4}{ }^{+}-\mathrm{N}: 1.5 \mathrm{mg} / \mathrm{L}$; TP: $0.3 \mathrm{mg} / \mathrm{L}$ ), which can reduce the impact of tailwater on the waters of the Tai Lake Basin. The successful implementation of the project provides an ecological buffer zone for the CAMIP, which improves biodiversity and offers the area a wetland training and research platform. The project optimises the combination of different types of constructed wetlands. The main technology route is 'buffer tank-vertical flow wetland-pond and riparian wetlandsurface flow wetland-saturated flow wetland' (Fig. 6). The average effluent water of $\mathrm{COD}, \mathrm{NH}_{4}{ }^{+}-\mathrm{N}$ and $\mathrm{TP}$ are $20 \mathrm{mg} / \mathrm{L}, 1.0 \mathrm{mg} / \mathrm{L}$ and $0.02 \mathrm{mg} / \mathrm{L}$, respectively. The technology of this project has the following notable highlights:

- The wastewater is treated by ecological methods that utilise the biochemical cycle of nutrients and water to produce an effluent water close to natural conditions, creating conditions for a healthy food chain and sustainable ecological cycle.

- The wastewater is distributed into the wetland by using gravity flow (zero-energy), combined with a solar power station which, together, achieved a low energy demand, greatly reducing operating costs. This solved the problem of high energy consumption of traditional techniques for treating a large volume of lowconcentration wastewater.

- Through precise design and construction, the constructed wetland realises automatic control and intelligent operation and maintenance. It is a stable self-learning system that

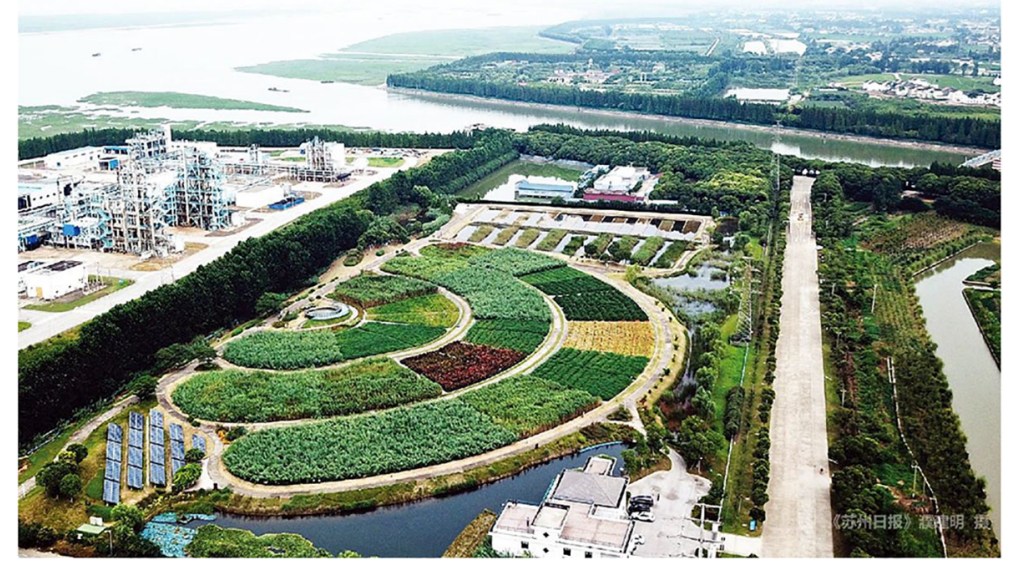

Fig. 6 Layout and performance of the industrial wastewater treatment constructed wetland 
has been operating stably for more than 6 years, effectively treating a large volume of complex quality wastewater from the CAMIP.

- The project has reduced the discharge of wastewater to the Yangtze River by approximately 9 million tons $\left(\mathrm{m}^{3}\right.$ wastewater) per year and sequestered around 72.3 tons of carbon $\left(\mathrm{CO}_{2}\right.$ equivalent) per year.

The project has been honoured as 'the Changshu Ecological Civilization Education Base', the 'Changshu New Era Civilization Practice Activity Site', the 'Field Workstation of the Jiangsu Academy of Environmental Sciences' and the 'Teaching \& Practice Base of the Environmental College of Hohai University'. It has also become a science education base for elementary and middle school students. During the project operation, more than 3000 visitors from government, companies and associations have visited the wetland. It has also received 5000 visitors from universities, primary schools and vocational schools.

\section{An African Perspective-'Nature's Ecological Engineers': The Role of Dung Beetles and Other Nature-Based Solutions in Alleviating Soil Compaction for Improving Grazing Systems}

\section{The Problem of Soil Compaction in Mining and Agriculture}

Soil compaction is regarded as one of the most significant challenges facing the rehabilitation of mined land [76]. So much so that prescriptions for alleviation are included in several international good practice mine rehabilitation guideline documents [77-82]. Soil compaction is not only synonymous with mined land but is also one of the major problems facing modern agriculture, a result of the overuse of machinery, intensive cropping, short crop rotations, intensive grazing and inappropriate soil management [83]. As soil is a highly valued and non-renewable resource, particularly for food security, the prevention and rectification of soil compaction are critical [84, $85]$.

\section{Traditional Versus New Innovative Approaches to Alleviating Soil Compaction}

Soil compaction increases soil bulk density and decreases soil porosity and is therefore managed in the agricultural setting via: (i) addition of organic matter; (ii) controlled traffic; (iii) mechanical loosening such as deep ripping; and (iv) electing a rotation which includes crops and pasture plants with strong tap roots able to penetrate and break down compacted soils [83]. Mine rehabilitation guidelines commonly advocate, often costly, ripping or tillage using machinery $[78,81]$. On compacted soil, poor vegetation cover prevails due to hostile soil conditions restricting plant root development.

Current rehabilitation methods of soil amelioration do not account for the abovementioned impacts and changes in soil properties and eventually equate to thousands of hectares being rehabilitated sub-optimally. Chemical and organic ameliorants are generally advocated in available guidelines. Although organic ameliorants are recommended, their quantities and qualities are limited since their value is underestimated. Organic ameliorants may include biosolids, animal manures, compost, and sawdust. One factor that has been shown in research to mitigate and alleviate compaction is the incorporation of different organic materials into 
structureless soil placed over levelled spoil material. These organic materials need to be categorised and blended for sustainable effect.

Traditional chemical ameliorants may include phospho-gypsum, liming, fertilisation and humic products, products derived from coal, and artificial flocculants such as polyacrylamide. With proper regulatory guidelines, siliceous fly ash, a coal combustion by-product, can be a valuable soil ameliorant which can address chemical, physical and microbiological challenges prevalent in degraded mined soil [86-88]. Due to the acidic nature of many mined surface soils, amelioration of $\mathrm{pH}$ is imperative.

With the understanding of the chemical, physical and biological nature of industrial, agricultural and other organic materials, blended ameliorants can be produced that will increase the sustainability of soil ameliorants used in the rehabilitation of degraded soils. The benefits of using traditional and/or new innovative approaches needs to be assessed based on their potential negative effects, ease of use and potential high costs. One challenge remains with the development of practical methodologies and specific equipment to apply and incorporate these different ameliorants unless blended prior to application and incorporation into the soil [89].

\section{Ecological Engineering Approaches, Challenges, and Benefits}

More holistic and nature-based solutions to alleviating soil compaction are required. The use of dung beetles for improving soil properties, including soil compaction on mined land is one such intervention that shows promise (Fig. 7). In line with the principles of ecological engineering, according to Schönborn and Junge [17], the use of dung beetles for soil improvement is an example of how ecological principles, processes and organisms can be combined with engineering practice in a holistic approach for problem solving.

Research work by Dabrowski et al. [90] aimed to determine if dung beetles can tunnel into compacted soils and how a range of soil penetration resistance may influence their tunnelling depth. Three beetle species were used: Onitis alexis, Digitonthophagus gazella and Euoniticellus intermedius. The study was conducted on a reclaimed section of an open-cast coal mine in eMalahleni, Mpumalanga Province, South Africa. The study concluded that all

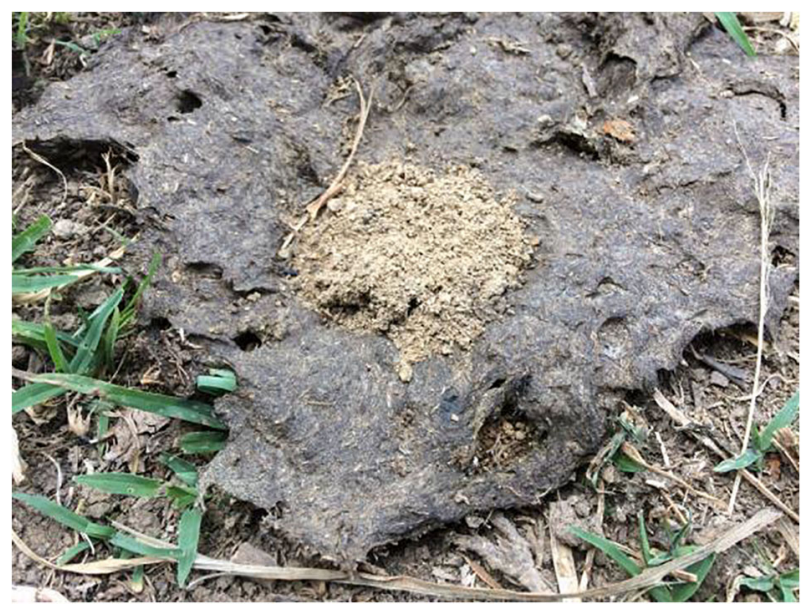

Fig. 7 Clay soil casts on a cow pad indicating dung beetle activity [70] 
three species could tunnel into the soil at an average penetration resistance of $3193 \mathrm{kPa}$ and even beyond the maximum measurement limit of the penetrometer at $5000 \mathrm{kPa}$. Reclaimed mined sites frequently have values exceeding $3000 \mathrm{kPa}$. While these results show promise, it was noted that large numbers of dung beetles with adequate dung sources would need to be imported onto mine sites undergoing rehabilitation. The study suggested a holistic approach of attaining dung from nearby farms or allowing grazing animals (such as cattle) on reclaimed land as part of the rehabilitation process. It was also noted that the three species used in the study are well known to be prolific breeders and could be bred for release in high numbers to supplement natural populations. An associated research study by Badenhorst et al. [91] similarly showed that water infiltration rate and plant biomass was significantly higher for confinements containing dung beetles, while penetration resistance (soil strength) was significantly reduced by dung beetles, and that magnesium and potassium levels were significantly higher. In conclusion, the study noted that the biological approach may prove to be cost-effective over time as it provides a seasonal source of bioturbation which does not disturb plant growth and reduces the requirements for soil rejuvenating tillage practices.

\section{A Middle East Perspective-Exploiting Water and Waste in the Desert Environment}

The Middle East region is well known for its abundant oil reserves and hot, dry climate. The region is officially one of the driest areas and most water-stressed regions in the world [92]. However, the continuous urbanisation, industrialisation, population growth and a growing agricultural sector all contribute to increasing water demand and pressure of the region's limited freshwater resources. Over-abstraction and unsustainable use of groundwater has lowered aquifers and intensified sea water intrusion [93]. At the same time, oil and gas exploration and production generate polluted water constituting one of the world's largest industrial waste-water streams [94]. Millions of cubic metres of oily wastewater (also known as produced water) contaminated with residual hydrocarbons, salts, heavy metals and various organic and inorganic pollutants are generated on a daily basis. Currently, the most common produced water management practice is deep well disposal (DWD), i.e., re-injection into reservoirs. This process not only consumes huge amounts of energy, but also poses a significant environmental risk. Hence, solutions provided by ecological engineering and technology are increasingly in demand in this industrial sector.

One notable example of such a solution was implemented in Oman by the national oil company (Petroleum Development Oman). A Constructed Wetland (CW) facility was built to treat up to $175,000 \mathrm{~m}^{3} /$ day of produced water from a nearby oilfield. This nature-based treatment facility is the largest CW system in the world for any type of industrial effluent, covering an area of almost 500 ha of wetland cells [95]. In this system, the breakdown of pollutants (mainly oil hydrocarbons) takes place through natural treatment processes and natural materials. The treated effluent complies with the strict discharge limit of $0.5 \mathrm{ppm}$ for total petroleum hydrocarbons. Comparison with the previous management solution of DWD showed a $90 \%$ reduction in operation and maintenance costs, while the carbon footprint was reduced by $99 \%$ [93].

Additionally, the current growing demand for circular solutions, closed material loops and waste exploitation enabled a series of activities in this facility. The treated industrial effluent was used to irrigate an agricultural field of 22 ha where different crops and plants were tested [95]. The goal of this practice was not simply to reuse the treated water, but to create an additional revenue stream and provide local job opportunities. 
Hence, crops with a potential market value were irrigated such as biofuel plants and cotton trees $[93,96]$.

The effluent was further leveraged by production of compost using reed biomass from the wetland cells in combination with small amounts of food waste and municipal sludge. The compost can be recycled in the adjacent agricultural field. The reed biomass was also tested for biogas production, which has the potential to offset the small energy demand for the operation of the whole facility [95]. The constructed CW system provides new habitat for wildlife in the desert environment, with more than 130 migratory bird species identified to be using the area as a stop-over during their journey. The CW system also has a positive effect on the microclimate of the area, reducing temperature by up to $10^{\circ} \mathrm{C}$ over a perimeter up to $1 \mathrm{~km}$ surrounding the CW cells [97].

This large, nature-based system in the Middle East represents an exemplary case study demonstrating the capacity of ecological engineering to provide solutions that go beyond the pure technical scope to integrate diverse disciplines, provide various social and environmental benefits and contribute to the transition towards a circular economy in the water sector.

\section{The Importance and Need for Ecological Engineering Education}

\section{Ecology}

Ecology is defined as the relationship of plants and living creatures to each other and their environment [98]. Ecology is a broad field with numerous levels of organisation spanning a wide range of spatial and temporal scales [99]. Several authors have aimed to address the need for a set of core themes and principles for application to both environmental management and education.

Motivated by the lack of a short, manageable list of broadly applicable environmental education standards Mengak et al. [100] defined a list of eight ecological principles identified as the most common general themes in all environmental studies.

In response to the importance of land management as a fundamental source of change in the global environment and perception that many decisions about the management and use of land are made with scant attention to ecological impacts, Dale et al. [101] identified five principles of ecological science that have implications for ensuring that fundamental processes of Earth's ecosystems are sustained.

In exploring the need to provide students with the skills necessary for problem-solving, critical thinking, and the integration of interdisciplinary concepts, and to address the fragmented nature of common teaching approaches, Barrett et al. [1] proposed the levels-of-organisation concept, spanning the range from cell to ecosphere $[99,102]$ as a framework for teaching environmental science and analysing ecological problems across broad temporal and spatial scales.

The alignment and divergence between the perspectives of Mengak et al. [100], Dale et al. [101] and Barrett et al. [1] on the central themes of ecology and environmental education is summarised in Table 1. The more comprehensive scope of concepts covered by Mengak et al. [100] and Barrett et al. [1] reflects the focus of these authors on education, while the scope of Dale et al. [101] identifies the sub-set of principles of greater importance for practical application to land use management.

Despite divergences, all these authors emphasise the need for recognition that ecosystems are spatially and temporally dynamic and that ecosystem function depends on ecosystem structure and diversity and the need for management to consider an integrative, whole-of-system focus. 
Table 1 Comparison of key themes in ecological education and practice

\begin{tabular}{|c|c|c|}
\hline Mengak et al. [100] & Dale et al. [101] & Barrett et al. [102] \\
\hline $\begin{array}{l}\text { Adaptation: The way a life system } \\
\text { looks or behaves is not random } \\
\text { or accidental; rather, it is the } \\
\text { result of changing to survive in a } \\
\text { dynamic environment. }\end{array}$ & $\begin{array}{l}\text { Species: Particular species and } \\
\text { networks of interacting species } \\
\text { have key, broad-scale } \\
\text { ecosystem-level effects. }\end{array}$ & $\begin{array}{l}\text { Evolution: Evolution by natural and } \\
\text { artificial selection involves } \\
\text { genetic changes at the species } \\
\text { level; coevolution (e.g., } \\
\text { mutualism) at the community } \\
\text { level; and long-term environ- } \\
\text { mental changes at the landscape } \\
\text { level in response to } \\
\text { human-caused habitat fragmen- } \\
\text { tation and global climate change. }\end{array}$ \\
\hline $\begin{array}{l}\text { Energy flow: Energy cannot be } \\
\text { created nor destroyed but it can } \\
\text { change form. Energy quality is } \\
\text { always degraded through }\end{array}$ & & $\begin{array}{l}\text { Energetics: The laws of } \\
\text { thermodynamics underpin } \\
\text { metabolism at all levels, from } \\
\text { cells to the ecosphere. }\end{array}$ \\
\hline
\end{tabular}

transformation.

Behaviour: Living systems evolve behavioural responses to stress and disturbances to enhance survival.

\section{Diversity: Changes in} environmental conditions over time have led to variety within each level of organisation.

Emergent properties: When different levels of organisation are functioning together, new properties are created that were not operational at lower levels.

\section{Growth and development: As} organisms and systems increase in size, changes occur that allow survival. Growth rate slows as maximum capacity is met.

Regulation: Energy is spent if a signal is sent to increase or decrease some function to maintain balance.

Limits: There are limits to how much stress can be tolerated by living systems.
Disturbance: The type, intensity and duration of disturbance shape the characteristics of populations, communities and ecosystems.

Landscape: The size, shape and spatial relationships of landcover types influence the dynamics of populations, communities and ecosystems.
Behaviour: Living systems at all levels evolve behavioural responses to stress and perturbations-responses that enhance survival.

Diversity: The diversity of genes, cells, organisms and ecosystems is a hallmark of life on Earth and one of the reasons that life has survived and prospered despite periodic catastrophes.

Integration: As we move from one level to another, new properties emerge that were not operational at lower levels. The emergent properties concept provides an approach to documenting the importance of integration between levels as well as between species.

Development: Growth and development transcend all levels of organisation. An understanding of developmental processes is necessary to find cures for cancer, prevent overpopulation, conserve endangered species, restore damaged habitats and develop sustainable societies.

Regulation: Growth, differentiation and metabolic processes regulated at various levels from development of cells, body temperature control in organisms, population regulation in ant colonies, the interaction of top-down and bottom-up 
Table 1 (continued)

\begin{tabular}{|c|c|c|}
\hline Mengak et al. [100] & Dale et al. [101] & Barrett et al. [102] \\
\hline & $\begin{array}{l}\text { Place: Local climatic, hydrologic, } \\
\text { edaphic and geomorphologic } \\
\text { factors as well as biotic } \\
\text { interactions strongly affect } \\
\text { ecological processes and the } \\
\text { abundance and distribution of } \\
\text { species at any one place } \\
\text { Time: Ecological processes } \\
\text { function at many time scales, } \\
\text { some long, some short; and } \\
\text { ecosystems change through time. }\end{array}$ & $\begin{array}{l}\text { regulation of food chains, and } \\
\text { carbon dioxide-oxygen and other } \\
\text { global balances. } \\
\text { Spatial and temporal scale: The } \\
\text { levels-of-organisation concept } \\
\text { provides a basis for understand- } \\
\text { ing biological processes across } \\
\text { broad spatial and temporal scales. }\end{array}$ \\
\hline
\end{tabular}

\section{Engineering}

Engineering is variously defined as the creative application of mathematical, natural and computer sciences to design or develop structures, machines, apparatus, or manufacturing processes, or to utilise the materials and forces of nature; or to construct or operate the same with full cognizance of their design; or to forecast their behaviour under specific operating conditions; all as respects an intended function, economics of operation and safety to life and property, for the benefit of mankind to meet some recognised need [103, 104].

Environmental engineering is the branch of engineering concerned with protecting the environment by assessing the impact a project has on the air, water, soil and noise levels in its vicinity by studying the project's design, construction and operation and minimising any adverse effects that it may have on the environment. It also involves mitigating problems caused by past activity, planning and design of equipment and processes for the treatment and safe disposal of waste material, directing the conservation and wise use of natural resources, and research and development of alternative energy sources, water reclamation, waste treatment and recycling [105].

Various authors have cast the role of engineers as being to solve problems, and the result of their work is the development and production (or improvement) of a product or process. This has been contrasted with the role of scientists as being to attempt to understand how the natural world functions, with the result of their work being the expansion of knowledge, often in the form of a publication or research paper [103]. This perception overstates the role of engineers and understates the role of scientists in solving problems and delivering real-world applications. In contrast, NAE [106] highlight examples demonstrating that the intersection of scientific knowledge and engineering has spawned new knowledge and curricula that have helped create or refine products for the benefit of mankind.

\section{Integration and Interdisciplinarity}

Barrett et al. [1] argued that students at the college level are frequently deficient in skills necessary for problem-solving, critical thinking and the integration of interdisciplinary concepts. They further argued that science has become fragmented and specialised, increasing the 
mismatch between traditional academic disciplines and real-world problems, and that the trend to specialisation is a recipe for error because the comprehensive picture may go unrecognised, or the specialist may overemphasise the significance of data in their own field, while it is the interfaces between disciplines that are relevant to solving practical problems [1,2].

Clark and Wallace [2] argue that today, there is a surplus of pseudo-integrative academic offerings springing from different origins, interests and individuals, but how to obtain, classify and organise knowledge and then use it to foster sustainability and other goals is one of the most fundamental problems that humanity faces. Clark and Wallace [2] posit that disciplinary courses fall far short in developing integrated skills for real-world problem solving and that integrative skills via a practical interdisciplinary method are essential for effectiveness in problem-solving. Similarly, Barrett et al. [1] emphasise the need for a structured framework to provide an integrative approach for analysing problems across broad temporal and spatial scales and socioeconomic components of resource management that can improve the critical-thinking and problem-solving skills necessary for dealing with long-term, large-scale problems.

Accordingly, an effective integrated offering of ecological engineering requires both the disciplinary offering of ecology and engineering, but also an explicit, systematic, comprehensive and practical framework to equip students and practitioners with the tools for knowledge integration [2] essential to address what Biermann et al. [3] describe as the urgent need to 'transition to more sustainable paths.'

\section{Ecological Engineering}

Many authors have attempted to define the nature of ecological engineering and, like the field itself, the definition has evolved over time. Odum [108] described ecological engineering as 'the management of nature ... an endeavour with singular aspects supplementary to those of traditional engineering'. In 1983, Odum described ecological engineering as 'the engineering of new ecosystem designs ... that use systems that are mainly self-organising'. Mitsch and Jørgensen [9] defined ecological engineering as 'a field that involves the design, construction and management of sustainable ecosystems that integrate society's needs with the natural environment for the benefit of both'. Schönborn and Junge [17] have suggested broadening the definition of ecological engineering to 'integration of ecological principles, processes and organisms with existing engineering practice into a holistic approach for problem solving'.

Articulation of the difference between environmental engineering and ecological engineering is critical to demonstrating the need for, and importance of, the discipline. Environmental engineering bears similarities to ecological engineering, but there is wide agreement that it constitutes a distinct field [9, 17, 107, 109].

Allen et al. [107], Mitsch and Jørgensen [9] and Schönborn and Junge [17] identify environmental engineering as operating within an explicit set of goals that bound the range of possibilities leading to realisation of solutions using informationally closed materials and/or biological organisms (with narrowly defined properties) to deliver a solution with tightly defined performance and reliability characteristics. In contrast, ecological engineering operates at the system level, contributing to the definition of goals that meet environmental, social and economic objectives, created using informationally open (selforganising) ecological systems and the process of autopoiesis (self-definition) as materials. 
In this context, environmental engineering solutions can be considered controlled by design, deterministic and static for their design life, while given the inherently dynamic nature of ecological systems, ecological engineering solutions can be considered guided by design, probabilistic and dynamic given the self-organising nature of ecological systems.

Allen et al. [107] argue that the dynamic and self-organising nature of ecological systems prevents the realisation of useful designs as environmental/operating conditions change, while conventionally engineered solutions have a defined performance and lifespan. However, in reality, the reliability of conventionally engineered solutions is limited within defined operating conditions, and performance reliability may be an illusion where environmental conditions are not fully accounted for in a design. In contrast, the self-organising nature of ecological systems is adaptive to changes in environmental conditions, providing resilience where design criteria recognise and allow for system function within a probabilistic range of environmental conditions. For example, geotechnical systems such as landfills, tailings storage facilities (TSFs), rehabilitated mine slopes and levees are required to perform safely throughout their service life which can span from decades to in perpetuity, based on the implicit assumption that the soil properties are stable through time. However, DeJong et al. [12] note that this is counter to long-term field observations of these systems, particularly where ecological processes such as plant, animal, biological and geochemical activity are present. In contrast, a rehabilitated forest, or wetland system or a rehabilitated mine site where ecological processes are re-established can be expected to change over time as plant communities move through successional stages and microbial activity re-establishes a biologically active soil profile; however, these systems can continue to deliver environmental and societal services such as clean water, soil stabilisation, nutrient re-use and carbon sequestration without the need for significant 'infrastructure' maintenance. Simplified, it is the capacity for adaptive design of ecological engineering that distinguishes it from the more formal, deterministic design of environmental engineering. This defines the need for a different approach to education and training based on systems thinking and design based on guiding ecosystem function within a probabilistically defined range of performance. These features, in turn, dictate the need for a dedicated curriculum to enable realisation of the environmental and social benefits of this integrative discipline.

\section{Scope for a Universally Recognised Curriculum in Ecological Engineering}

\section{Design of a Unified Course in Ecological Engineering}

As demonstrated in the preceding section, limitations of both ecology and engineering are addressed in the integrated field of ecological engineering. Ecological engineering combines basic and applied sciences from engineering, ecology, economics, natural and social sciences in a blend of ecology and technology that may be applied to the restoration, construction and management ecosystems through adaptive design. In so doing, ecological engineering provides an umbrella for a range of established and emerging disciplines including nature-based solutions, constructed wetlands, green buildings (including roofs, facades, cooling systems, indoor climate, energy supply), biospherics, recirculating production systems and circular water reuse systems.

Ecological engineering promotes avoidance strategies and utilises low-energy approaches to manage natural, constructed and industrial systems. It relies on a systems approach to problem 
solving, conserves non-renewable energy sources and supports biological conservation. It treats waste as a resource and promotes sustainable development, 'development that meets the needs of the present without compromising the ability of future generations to meet their own needs' [110]. Ecological engineering involves practical solutions that require a sound understanding of how our environment works and an appreciation of the dynamic nature of ecological systems.

Ecological engineering may complement conventional engineering approaches, utilise part of them or make use of technically augmented semi-natural ecosystems. The focus on incorporation of ecological principles and systems in adaptive engineering design to promote development of robust, sustainable systems distinguishes ecological engineering from other engineering disciplines.

Based on the preceding considerations, a curriculum for ecological engineering is proposed that recognises a set of core overarching principles and concepts that unite multiple application areas of specialist disciplinary knowledge in ecological engineering practice. The structure of the proposed curriculum is illustrated in Fig. 8. Core principles and concepts and Specialist application areas are discussed below.

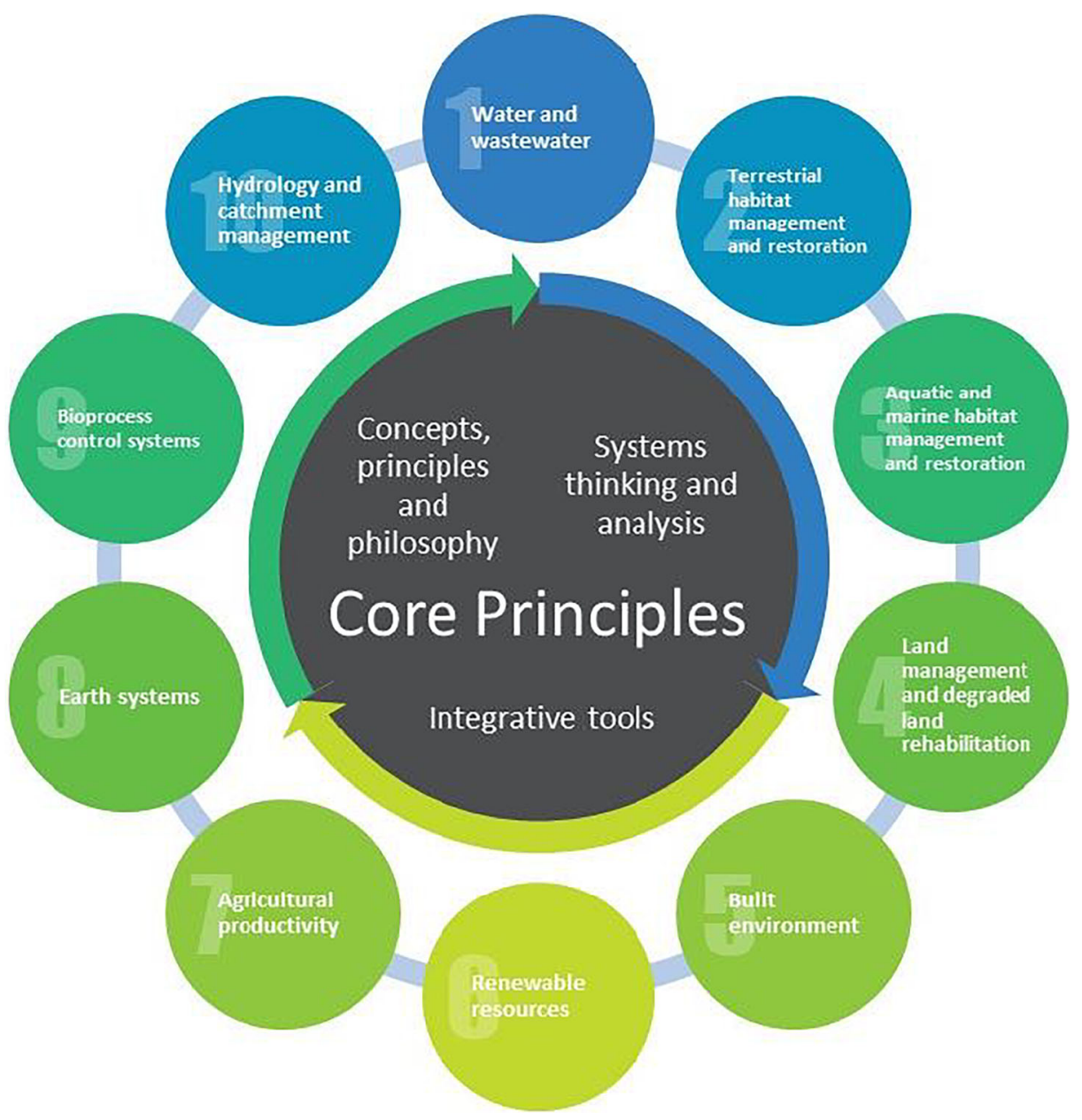

Fig. 8 Proposed ecological engineering course structure illustrating core concepts and specialist activity areas 


\section{Core Overarching Principles and Concepts}

Borrowing from both theoretical ecology [1] and educational science [2], it is argued that a structured systems approach to conceptualising problems of design incorporating ecological principles is a central tenant and distinguishing feature of ecological engineering practice. To this end, the core curriculum structure presented in Table 2 is proposed.

At the end of the core course, a student should have the capability and tools to analyse problem attributes and design practical solutions to complex problems.

\section{Specialist Activity Areas}

Elective courses provide the capacity to explore key applications of ecological engineering and contrast these to conventional engineering approaches. Through the range of identified applications, the scope of ecological engineering electives is currently identified to span ten specialist activity areas, but the applications of ecological engineering may extend to any human interaction with the natural environment. The scope of specialist application areas presented in Table 3 is proposed.

Table 2 Proposed core curriculum structure

\begin{tabular}{|c|c|}
\hline Module & Content \\
\hline Concepts and principles & $\begin{array}{l}\text { - Definition and scope of ecological engineering and overlap with other related } \\
\text { disciplines } \\
\text { - Sustainable development and circular economy concepts } \\
\text { - Cyclic problem-solving design process for engineering } \\
\text { - Holistic, integrative, systems-based approach to thinking } \\
\text { - Attributes based approach to problem definition and problem solving } \\
\text { - Ecosystems ecology } \\
\text { - Learning from nature and mimicking nature } \\
\text { - Energy flows, cycling of materials and nutrients in natural and artificial systems } \\
\text { - Resource conservation, reuse, recycling and waste minimisation } \\
\text { - Conservation and land use planning } \\
\text { - Principles of green infrastructure and green buildings } \\
\text { - Ancient and geographically adapted ecological engineering cases. } \\
\text { - Social acceptance, stakeholder consultation and citizens participation }\end{array}$ \\
\hline $\begin{array}{l}\text { Systems thinking and } \\
\text { analysis }\end{array}$ & $\begin{array}{l}\text { - Quantitative approaches to ecology } \\
\text { - Probabilistic as opposed to deterministic approaches in design } \\
\text { - Environmental economics and valuation } \\
\text { - Five capitals / Sustainable operations (SUSOP) } \\
\text { - Life Cycle analysis / System dynamics/Cradle to cradle design }\end{array}$ \\
\hline Integrative tools & $\begin{array}{l}\text { - Systems analysis and modelling tools, e.g., for system border-, network-, } \\
\text { circularity- and mutual benefit-analysis } \\
\text { - Interdisciplinary analytic framework for problem-solving } \\
\text { - Thermodynamics and energy transfer processes } \\
\text { - Programming methods relevant to ecological engineering } \\
\text { - Professional ethics and social responsibility } \\
\text { - Communication and technical writing }\end{array}$ \\
\hline
\end{tabular}


Table 3 Specialist activity areas

Module
1. Water and wastewater
2. Terrestrial habitat management and
restoration (Vegetation and Wildlife)

restoration (Vegetation and Wildlife)

3. Aquatic and marine habitat management and restoration

4. Land management and degraded land rehabilitation (Soil)

5. Built environment

6. Renewable resources

7. Regenerative agriculture

8. Earth systems

9. Bioprocess control systems

10. Hydrology and integrated catchment management
Content

Natural and constructed wetlands; Irrigation management; Soil-water-plant interactions; Plant water use (Penman-Monteith); Land treatment of wastes; Ecological sanitation; Effluent and biosolids; Water recycling strategies; Circular water systems; Water-Soil-Waste Nexus.

Ecosystem restoration; Island Ecology; Revegetation; Conservation genetics; Soil surveying and functional characterisation; Land capability assessment; Plant-soil-water interaction; Soil and plant nutrition; Soil health and restoration; Plant growth and nutrition; and Biodiversity.

Estuarine, coastal and marine ecology; Riverine ecosystems; Groundwater dependent ecosystems; The role of the marine environment in buffering the carbon cycle; Nutrient cycling and eutrophication; Point source pollution and mixing; and Aquaculture systems in natural habitats.

Mined and degraded land rehabilitation; Contaminated site rehabilitation; Point source pollution and mixing; Diffuse source pollution and sediment transport; Erosion processes, soil stabilisation and sediment management; Soil surveying and functional characterisation; Plant-soil-water interaction; Plant growth and nutrition; Soil health and restoration; Salinity and sodicity; Geomorphology of reclaimed land; and Bioremediation.

Urban heat island and counter-measures; Green infrastructure in city planning; Visual, acoustic and dust screening; Completely recyclable building and packaging materials; Water sensitive urban design; Urban water cycle; Urban hydrology; Integrated ecological buildings; Passive shading and heating; and Zero- or Plus-energy buildings; Circular water systems.

Forestry; Bioenergy; Biogas and anaerobic digestion; Natural resource management; Nutrient recycling (biosolids, feedlot wastes, composting; and Water management (settlement-, catchment- and global scale).

Integrated pest management; Integrated soil water management; Windbreaks, alley farming, stock shelter; Rotational grazing; Natural soil cultivation (worms, dung beetles); Soil surveying and functional characterisation; Land capability assessment; Soil health (physical/chemical/biological) and restoration; Livestock management; Agricultural engineering; and Genetics and breeding; Water-Energy-Food Nexus.

Global environmental processes; Climate change and carbon sequestration; Air quality and pollution; Water quality and pollution; Carbon cycle; Water/Hydrologic cycle; Nitrogen cycle; Phosphorous cycle; and Environmental Transport \& Mixing.

Microbial fuel cells; Food engineering and processes; Aquaponics; Metabolic systems engineering; and Recirculating algae production system.

Hydrology; Hydrogeology; Hydrologic cycle; Hydrogeology; Integrated water resources management; Stochastic hydrology; Fluvial processes; River engineering; Soil-water-plant interactions; Plant water use (Penman-Monteith); Catchment management; and Groundwater recharge, infiltration and storage. 


\section{Challenges and opportunities to adoption of Ecological practice}

\section{Challenges to wider adoption of Ecological Engineering}

\section{The Need for Innovation in Engineering}

Society is blessed by the contribution, caution and integrity of the engineering disciplines which influence every aspect of our lives $[17,107]$. The word engineering derives from the Latin, ingeniator ('to create, generate, contrive, devise') and ingenium ('cleverness'). Engineering is synonymous with skill in planning, combining and adapting - using science and practical ingenuity, to identify problems and find solutions [106].

Over the past 70 years, engineering has contributed to technology developments delivering previously inconceivable benefits for humankind, including the remarkable feat of bringing more people out of poverty than in all of history [111]. Over this period, the number of people living in extreme poverty has fallen from $63 \%$ in 1950 to $10 \%$ in 2015, while at the same time, population has risen from 2.5 billion to 7 billion [112]. However, these benefits are being achieved at the expense of the environment and the natural world.

The United Nations Development Programme Human Development Report 2020, 'Human development and the Anthropocene' [4] acknowledged that no country in the world has yet achieved very high human development without putting immense strain on the planet. The report argues that the next frontier for human development will require working with and not against nature while transforming social norms, values and government and financial incentives.

The increasing pressure on the earth's ecosystem will demand new insights, knowledge and solutions. In 2004, the US National Academy of Engineering recognised the need and opportunity for engineering to adapt, use new tools, apply ever-increasing knowledge in expanding engineering disciplines and become increasingly applied in ways that achieve synergy between technical and social systems [106].

The integrated discipline of ecological engineering offers such innovation and new tools in engineering by recognising the imperative to provide benefits to both society and the environment. However, adoption of such tools, while growing, remains a niche area of engineering without formal recognition at the discipline level ${ }^{2}$ through any known engineering accreditation agency despite formal calls for such accreditation since at least 2001 [112]. Engineering may be a victim of its own success, limiting its evolution into the sphere of ecology.

\section{Dominance of Engineering-Based Solutions in Government Corporate Procurement}

Through experience over the past 10 years of daily monitoring of private and public-works tender sites in Australia, we can anecdotally state that calls for tightly bounded engineering solutions, or simple ecological solutions lacking the rigour of quantitative design, vastly dominate calls for ecological engineering or nature-based solutions to environmental problems spanning the range of ecological engineering applications identified in Fig. 8 such as

\footnotetext{
${ }^{2}$ Ecological engineering courses offered by Oregon State and Purdue University in US have Accreditation Board for Engineering and Technology (ABET) accreditation. Zurich University of Applied Sciences (ZHAW) has delivered a specialisation in ecological engineering for more than 25 years.
} 
ecosystem recovery, waste treatment or ecosystem utilisation. Rather, based on our experience, we contend that ecological engineering solutions are more often promoted to private and public authorities either through direct relationships, or as an alternative option to requested services. This speaks to structural barriers to adoption of ecological engineering solutions, which may be attributed to inertia, lack of awareness or limits of responsibility:

i. The inertia of change from entrenched ways of solving problems: The culture of many large organisations favours tried and proven practices over innovation. This may be reinforced by the perception of greater risk in new approaches to solving problems over established practices. A survey of nearly 500 managers with Corporate Social Responsibly (CSR) accountabilities in Australia found: $80 \%$ of respondents agreed that CSR had contributed to strengthened reputation; $60 \%$ agreed that CSR had contributed to reduced risks, strengthened competitive advantage and created new value; and 60\% saw CSR had contributed to reduced costs [113]. Despite apparent recognition of the business case for CSR, respondents noted numerous barriers to adoption of CSR including lack of organisational commitment and buy-in (25\%), difficulties integrating CSR with organisational values $(12.5 \%)$ and difficulty of making the business case for CSR $(12 \%)$. These results indicate the reluctance of organisations to embrace change, even when there are clear benefits. In addition, the survey found that change is often driven by individual champions. Where receptiveness to change is not 'mainstreamed', organisational appetite may wane when the champion moves on.

ii. The relative newness of ecological engineering: This barrier also speaks to the flow-on effect of limited education in ecological engineering, and the lack of a pool of graduates moving through technical practice and into decision making roles, and associated lack of familiarity with ecological engineering as an option to common problems facing society and the environment.

iii. The tragedy of the cycle (Fig. 9): Many organisations have the capacity to deal with problems within their direct influence but have less appetite or capacity to address system

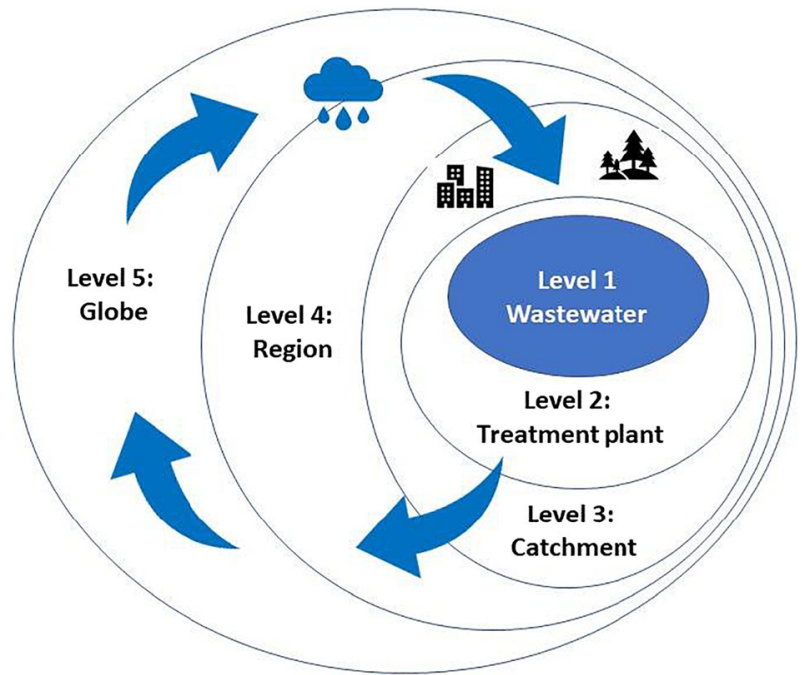

Fig. 9 The 'tragedy of the cycle'. Solutions for local problems level $1+2$ (wastewater and how it is treated) can affect the regional and global water cycle (level 4+5) if specific engineering solutions become paradigmatic 
issues that could provide more holistic and enduring outcomes. For example, water authorities may deal with high sediment or nutrient loads in rivers by installing additional 'grey engineering' water treatment infrastructure, when the more cost-effective and holistic solution may be riparian restoration to prevent streambank erosion and filter agricultural runoff, with co-benefits including habitat connectivity, carbon sequestration and improved water for aquatic habitats. However, the holistic solution requires development of relationships with landowners outside the direct control of the water authority, and often outside the expertise and comfort zone of water engineers.

The anecdotal observation of barriers to adoption of ecological engineering solutions across a broad range of applications is also reflected in more specific applications. In a substantial review of barriers to adoption of nature-based solutions (NBS) in urban applications, Mačiulyte and Durieux [114] found many public authorities report difficulties in using public procurement to implement NBS projects. Challenges limiting procurement of NBS included lack of knowledge and experience with NBS; lack of NBS typology classifying the type of service or works to be procured and their corresponding performance, notably where a degree of innovation is required to develop technologies that are adapted to specific local circumstances; difficulty finding skilled suppliers; challenges in community engagement; institutional and legal barriers; perceived reputational risk; and limited access to funding [114].

These barriers speak to the need for greater awareness of the potential contribution and place of ecological engineering via both a top-down understating from decision-makers and bottom-up pool of trained graduates.

\section{Structural Focus of Environmental Protection Authority Legislation}

At the end of the World War II, the USA led an effort to create a system of international agreements and institutions based on two pillars - economic development as well as social development or human rights predicated on a foundation of peace and security [115]. In the 1970s and 1980s, it became evident that poverty and environmental degradation are interrelated and that the development model needed to be modified. The 1980 International Union for Conservation of Nature report 'World Conservation Strategy: Living Resource Conservation for Sustainable Development' [116] identified the need to integrate conservation and development in the form of 'sustainable development'. The report acknowledged the difficulty of merging the concepts of conservation and development noting that, at the time, they have 'so seldom been combined that they often appear - and are sometimes represented as beingincompatible' [116]. Today, we understand sustainable development as 'development that meets the needs of the present without compromising the ability of future generations to meet their own needs' [110].

Around the world, Environmental Protection Agencies (or their equivalent), enact and enforce legislation for protection of the environment and human health. At a practical level, this includes applications for new developments; management of environmental contamination; or impacts to land, water, air etc. However, EPAs do not necessarily implement programmes of sustainable development. Rather, their function and guiding legislation is often around minimising environmental impact. For logistical reasons, this is often on a location and project-specific basis, though not always in the case instruments such as load-based licencing. 
As an example, the functions of the EPA for the State of Western Australia are: conducting environmental impact assessments, preparing statutory policies for environmental protection, preparing and publishing guidelines for managing environmental impacts and providing strategic advice to government [117].

The consequences of the focus of EPAs on minimising impact rather than maximising environmental benefit are several:

- First, licencing development approvals based on minimising environmental impact narrows scope and focuses design around meeting minimum environmental requirements rather than considering options to create environmental benefits. This is well illustrated by infrastructure such as sewage treatment plants (STPs) that are often (though not always) designed around the narrow scope of treating sewage to produce effluent and biosolids to meet licenced river and land discharge criteria. In the process, STPs typically consume energy to convert nitrates and ammonium to nitrogen gas. This design paradigm for STPs is now changing, but has been dominant in recent decades.

- Second, it discourages wider systems thinking in solution design. Extending the STP example, sewage is part of a much larger water, nutrient, carbon and energy cycle. Energy is expended to extract natural gas and convert to nitrogen fertiliser and to mine finite deposits of phosphorous. These nutrients are used in agriculture and pass through the food cycle into sewage. Sewage water treatment to meet minimum environmental compliance expends additional energy destroying plant-available forms of nitrogen and fails to capture the opportunity to beneficially use water, return nutrients and carbon to agriculture, and to reduce pressure on primary nutrient sources.

- Third, it directs thinking to minimising environmental impact rather than considering opportunities to create positive environmental benefit. Again extending the STP example, design focused on minimising energy, capturing nutrients and maximising beneficial reuse in agriculture and/or habitat restoration will reduce the need to mine natural gas, reduce $\mathrm{CO}_{2}$ emissions in fertiliser production and nitrogen destruction, reduce demand and help conserve finite deposits of phosphorous, sequester carbon in soils, improve soil health (with benefits for erosion and nutrient use efficiency), improve water quality and aquatic habitats and lose the opportunity to enhance biodiversity through the use of water and nutrients in habitat restoration.

- Fourth, by licencing to minimise impact with each individual development, it may contribute to cumulative impacts across multiple developments, making it harder to maintain environmental quality as populations and/or economic activity grow. This may also occur with the increasing concentration of $\mathrm{CO}_{2}$ in the atmosphere despite per capita reductions in emissions.

- Fifth, design to the narrow scope of minimum environmental compliance misses the opportunity for new economic benefits and jobs through green growth. Opportunities seen by companies and organisations in the green economy provide the opportunity to challenge existing paradigms, create new jobs and business opportunities, and deliver environmental benefits, contributing to growth of the economy and enhancement of the environment.

- Sixth, it reinforces the paradigm of competition between development and the environment, diverting focus away from attribute-based design that shuns pre-conceived solutions, and explores real win-win opportunities for society and the environment as envisaged by 
the ethos of sustainable development and implemented through approaches such as the Five Capitals Sustainable Development Framework [31].

These considerations highlight the structural basis of environmental management fostered by common environmental legislation based on minimising environmental impact rather than maximising environmental benefit. They highlight the need for a different approach to thinking by environmental professionals involved in development to promote sustainable development solutions, as encouraged by the overarching approach to problem solving embodied in ecological engineering.

\section{The Adversarial Mindset Between Development to Benefit Society and the Environment}

As early as 1713, Hans Carl von Carlowitz, a chief miner from Saxony, formulated the principle of sustainability due to an impending shortage of wood. In his work "Sylvicultura oeconomica" [Carlowitz, 1713] he demanded that only as much wood may be felled as can be regrown through planned reforestation. In doing so, he laid the foundation for German forestry and the principle of sustainable use of raw materials. Similarly, Marsh [119], recognised that sustainability is based on a simple and, at the time, long-recognised factual premise that everything humans require for their survival and well-being depends, directly or indirectly, on the natural environment.

However, this self-evident connection was, for a period, lost with time. Between the end of the World War II and the 1980s, the concept of development as articulated by the international community was based on the two pillars of economic and social development or human rights [115]. Gradually it became evident that poverty and environmental degradation are interrelated. In 1972, the study "Limits to Growth" [120] for the Club of Rome caused a stir around the world in terms of environmental and development issues. The tension between development and environment was further highlighted by the IUCN report 'World Conservation Strategy: Living Resource Conservation for Sustainable Development' [116] which identified the need to integrate conservation and development in the form of 'sustainable development'.

It was not until the 1992 UN Conference on Environment and Development, known as the Rio de Janeiro 'Earth Summit', that the global community modified the definition of development to include the third pillar of environment, establishing the foundation for sustainable development [118, 122], and 1993 that the term 'triple bottom line' was coined to measure the financial, social and environmental performance of the corporations [121].

The concept of the triple bottom line has served a very valuable purpose in helping to make the environment explicit in financial decisions and evaluate the full cost involved in doing business [121]. However, although intended to provoke deeper thinking about capitalism and its future, it is often used as a simple accounting tool, and applied with the approach of trading off returns against each other [121], reflecting the ingrained paradigm of conservation and development being incompatible. Subsequently, the triple bottom line has been considered to be incomplete as it misses the cultural perspective, comparable to the cultural ecosystem services in the Millennium Ecosystem Assessment [123]. The proposed framework by Roetman and Daniels [124] is considered the quadruple bottom line, which means 'Adding purpose to the mix'.

The concept of doughnut economics [125] re-discovers von Carlowitz and Marsh's observations. Appreciation of this theory reveals that there is no economics without a healthy environment, that society and the economy exit within the environment and that the 
environment is not something to be traded off against profits, but is the foundation for generating profits. The theory also provides the basis for new economic activity based on green growth, decoupling environmental pressure from economic growth.

A combined economic and environmental modelling study found that strong carbon abatement and resource efficiency policies could have negligible impact on economic growth and employment, and not compromise efforts to raise human wellbeing and standards of living until 2050, while reducing global material and energy use and carbon emissions [126]. Similarly, the green technology and sustainability market size is projected to generate market opportunities of over $\$ 12$ trillion a year by 2030 [127].

A further development is the theory of ecological economics [128] that goes beyond the green growth decoupling concept as well as the approaches of environmental economics. Ecological economics is a transdisciplinary field of science that deals with the research of options for action in view of the ecological limits of the carrying capacity of natural systems. It follows the knowledge of the natural sciences that the earth's ecosystem is limited and materially closed. The only input to planet earth comes from the sun, and heat is the only output. Ecological economics is based on a socio-ecological system connection between natural, socio-economic and cultural development. The discipline has significantly contributed to the development of methods and instruments to describe and estimate the value of ecosystems to humans (value of ecosystem services), not only through monetarization, but also through much broader valuing categories.

Rediscovery of the basis for sustainable development, combined with growing recognition for development to positively benefit the economy, society and the environment, generate new opportunities through green growth and decouple environmental pressure from economic growth, will not only require new interdisciplinary skills in science, engineering and economics; it will require new approaches to thinking about solutions to global environmental challenges. A well-designed ecological engineering course, with a core in integrated systems thinking and problem solving, is an important element of this transition.

\section{Confidence in Performance Reliability}

One part of the ecological engineering toolbox is self-designing ecosystems and the components of the biological species of the world. Thus, some tools and components of ecological engineering (ecosystems and living species) are dynamic in nature. These components respond to a multitude of inputs and conditions and therefore can behave without the precision of engineering disciplines that rely on materials with tightly specified properties. This can create a question in the performance reliability of ecological engineered designs. However, if natural or engineered ecosystems behave dynamically and are self-organising, they behave in statistically predicable ways in response to physical, chemical and biological conditions. This enables probabilistic, rather than deterministic bounds typical of more conventional design. Nevertheless, many ecological engineering designs have deterministic elements with predictable performance characteristics.

The principal of probabilistic behaviour can be demonstrated by crops irrigated to re-use and treat waste-water. Water use by evapotranspiration is a critical element of design. Insufficient crop area to utilise all produced water will have a down-stream consequence in overflows or uncontrolled discharge with potential to cause environmental harm, and an upstream consequence through the inability of the 'green' wastewater treatment system to support the essential function for which it was designed. Excess crop area will be financially inefficient and may result in other sustainability issues if irrigation volumes are insufficient to support healthy crops and soils. 
However, while crop water use is a function of a multitude of processes (species, growth stage, plant density, rainfall, evaporation, vapour pressure deficit, soil type, soil water holding, soil nutrition, crop management practices, soil microbiology, pests and diseases, etc.), these are all factors that can be characterised and understood. This allows water use (and variation in water use between seasons and years) to be modelled, and for beneficial re-use systems, providing human and environmental benefits, to be designed with a defined performance reliability.

While some authors and traditional engineers may argue that ecologically engineered systems lack the stability of system components typically associated with engineering [107], the reality is that engineered systems function within defined conditions, and the appearance of control is an illusion if these conditions are not sufficiently representative of actual operating conditions over time. In contrast, for ecologically engineered design it is inherently necessary to consider the broadest possible set of operating conditions, allowing these systems to potentially function more reliably than engineered systems that may not be adequately designed to withstand mutating ecosystem pressures.

While some traditional engineering departments may be unwilling to embrace an emerging curriculum that offers solutions that provide good, but not precise solutions from a deterministic perspective, the relatively new science of ecological engineering is winning increasing acceptance worldwide where probabilistic design is embraced. In established industrial economies, initial scepticism and regulatory hurdles are giving way to burgeoning investments by companies and municipalities, increased research activity and substantial interest from the public at large [129].

\section{Opportunities to Increase Adoption of Ecological Engineering Practice}

\section{Progression of the Discipline of Ecological Engineering Through Practice}

Ecological engineering may be considered as much an idea as a discipline. The idea that environmental problems can be re-imagined in a systems framework, and new solutions found using a holistic approach, of which the tools of self-designing ecosystems and the components of living species can be a part.

Despite the limited development of formal courses, the case studies provided above illustrate that practical application is occurring around the globe and that practitioners are innovating applications of the common unifying concept. This observation is supported by other authors $[9,129,130,131]$. As with many other developing fields, practice is far ahead of theory. This presents the challenge for theory to catch up and help further advance practice. This is a realisation of Mitch's concept of the 'acid test' of our understanding of ecological systems [9].

Rather than see the complexity of dynamic, probabilistic systems as a barrier, it should be viewed as a challenge to better characterise, model and understand the complex processes of natural and semi-natural systems. Implementation of ecological engineering projects provides the capacity to undertake experiments testing the theory and our understanding of ecological principles at scale. The knowledge gained from learning by doing will provide richer data than can be obtained from small-scale experimentation, and will contribute to refining design parameters and processes that will progressively improve our knowledge bank/modelling capacity to enable delivery of progressively more predicable outcomes. Rapidly advancing technology for digital environmental sensing, combined with increasingly precise global positioning is allowing us to fully enumerate the environment at increasingly fine scale. 
Combined with advances in data-analytics, this will undoubtedly play a key role in our capacity to understand and model ecosystem behaviour to improve capacity for ecological engineering design.

\section{Recognising and Understanding the Place of Ecological Engineering}

Ecological engineering solutions are, by definition, low-energy approaches to solving environmental problems. Hence, ecological engineering solutions are not necessarily quick or space efficient but, by definition, they should not transfer problems from one place to another as illustrated by Mitch and Jorgenson's shell game [9]. This does not make ecological engineering solutions worse or better than environmental engineering options; it just makes them different. Understanding the differences between disciplines is key to appropriate application in the appropriate place and time. Not all environmental issues can be solved by ecological engineering, environmental engineering or any other ecotechnology. They all have a rightful place and are dependent on each other to contribute to design, implementation and realisation of solutions that deliver a more sustainable future.

In appreciating the place of ecological engineering and its role, the issue of precision comes into perspective. Ecological engineering is not the design of bridges or aeroplanes that must perform to tightly defined performance and safety criteria. It is the design of ecosystems or ecological sub-systems, and the provision of conditions that allow these systems to exist in a way that benefits the environment and delivers ecosystem services of value to society. At the same time, ecological engineering may improve our understanding of environmental process that impact engineered structures which may ultimately lead them to fail [12] and could contribute to reduced maintenance over time.

Recognition of the place of ecological engineering influences the perspective on the necessary level of precision. While the application of quantitative methods is a critical element of ecological engineering, the nature of the applications allows probabilistic design, where system function guided within a defined range of performance limits is sufficient to reliably delver services to society, of equal validity in terms of safety, investment and confidence to conventional engineering solutions.

\section{Building Confidence in Ecological Engineering Applications}

Where confidence in ecological engineering solutions as an alternative to grey infrastructure options may be lacking, the field may progress though practice in low risk settings to progressively demonstrate quantitative results. This may include either applications with lower criticality (such as the integration of dung beetles in grazing systems) or smaller examples of large-scale applications with high criticality (such as the example of coal seam gas water beneficial reuse). By extending the principle of learning through doing, this approach will progressively contribute to case studies providing confidence in the discipline and data to support continuing development of the underpinning theory.

Importantly, case studies will support understanding of fundamental processes (e.g., microbiological reactions) by contributing to demonstration of the cost-benefit value of ecological engineering applications, and robust methodologies to value ecosystem co-benefits, necessary to justify investment and encourage self-supporting adoption. 


\section{Education in Ecological Engineering}

By unifying the numerous specialist activity areas and applications of ecological engineering under an umbrella encompassing a set of core principles, approaches, tools and way of thinking that distinguishes ecological engineering from other engineering disciplines, it becomes possible to scale up implementation of the discipline and strengthen its impact in mitigating the world's most pressing challenges. These challenges can only be realised if ecological engineering moves beyond application by a relatively small band of enthusiastic practitioners, learning by doing, to the education of future cohorts of students who will become tomorrow's engineers, project managers, procurement officers and decision makers, applying principles informed by a growing body of theory and knowledge generated by an active research community, a need whose time has come, if we are to deploy all tools at our disposal toward addressing the grand challenge of creating a sustainable future.

Acknowledgements The authors acknowledge the useful comments and references provided by Yolandi Schoeman. This paper is an advance article to special issue of 'Circular Economy and Sustainability' featuring papers from the 'Closed Cycles and the Circular Society 2020' conference organised by The International Ecological Engineering Society.

Funding Open access funding provided by ZHAW Zurich University of Applied Sciences.

\section{Declarations}

Conflict of interest The authors have no conflicts of interest to declare that are relevant to the content of this article.

Open Access This article is licensed under a Creative Commons Attribution 4.0 International License, which permits use, sharing, adaptation, distribution and reproduction in any medium or format, as long as you give appropriate credit to the original author(s) and the source, provide a link to the Creative Commons licence, and indicate if changes were made. The images or other third party material in this article are included in the article's Creative Commons licence, unless indicated otherwise in a credit line to the material. If material is not included in the article's Creative Commons licence and your intended use is not permitted by statutory regulation or exceeds the permitted use, you will need to obtain permission directly from the copyright holder. To view a copy of this licence, visit http://creativecommons.org/licenses/by/4.0/.

\section{References}

1. Barrett GW, Peles JD, Odum EP (1997) Transcending processes and the levels-of-organisation concept. Bioscience 47(8):531-535

2. Clark SG, Wallace R (2015) Integration and interdisciplinarity: concepts, frameworks, and education. Policy Sci 23(8):233-255. https://doi.org/10.1007/s11077-015-9210-4

3. Biermann F, Campe S, Jacob K (2004) Knowledge for the sustainability transition and the challenge for social science - an introduction. In: Proceedings of the 2002 berlin conference on the human dimensions of global environmental change "Knowledge for the Sustainability Transition. The Challenge for Social Science". Global Governance Project, Amsterdam, Berlin, Potsdam and Oldenburg. isbn:3-00-014956-2

4. UNDP (United Nations Development Programme) (2020) The Next Frontier: Human Development and the Anthropocene. United Nations Development Programme (UNDP), New York, p 2020, 412pp. isbn: 978-92-1-126442-5

5. IPBES (Intergovernmental Science-Policy Platform on Biodiversity and Ecosystem Services) (2019) In: Brondizio ES, Settele J, Díaz S, Ngo HT (eds) Global assessment report on biodiversity and ecosystem services of the Intergovernmental Science- Policy Platform on Biodiversity and Ecosystem Services. IPBES Secretariat, Bonn, Germany. https://ipbes.net/global-assessment 
6. Barbieri M (2019) The decrease in life expectancy in the United States since 2014. Population \& Societies 570(9):1-4

7. Bennett JE, Li G, Foreman K, Best N, Kontis V, Pearson C, Hambly P, Ezzati M (2015) The future of life expectancy and life expectancy inequalities in England and Wales: Bayesian spatiotemporal forecasting. Lancet 386(9989):163-170

8. Budiansky S (1995) Nature's keepers: The new science of nature management. Free Press, Winnipeg, ME, USA. ISBN:0029049156

9. Mitsch W, Jørgensen SE (2003) Ecological engineering: a field whose time has come. Ecol Eng 20:363377

10. Laurance B (2012) Are nature reserves working? Take a look outside. The Conversation. https:// theconversation.com/are-nature-reserves-working-take-a-lookoutside-9432. pp. 1-4. (Accessed Apr. 10, 2021)

11. Yonzon P et al (2012) Averting biodiversity collapse in tropical forest protected areas. Nature 489(7415): 290-294

12. DeJong J, Tibbett M, Fourie A (2014) Geotechnical systems that evolve with ecological processes. Environ Earth Sci 73:1067-1082. https://doi.org/10.1007/s12665-014-3460-x

13. European Commission (2013a) Communication from the Commission to the European Parliament, the Council, the European Economic and Social Committee and the Committee of the regions: Green Infrastructure (GI) - Enhancing Europe's Natural Capital. Brussels, Belgium. http://eur-lex.europa.eu/ legalcontent/EN/TXT/?uri=CELEX:52013DC0249 (accessed Apr. 10, 2021)

14. USEPA (United States Environmental Protection Agency) (2014) Enhancing sustainable communities with green infrastructure. U.S. Environmental Protection Agency, Washington, DC EPA 100-R-14-006 October 2014. 66pp

15. Cohen-Shacham E, Walters G, Janzen C, Maginnis S (2016) Nature-based solutions to address global societal challenges. International Union for Conservation of Nature, Gland, Switzerland. https://doi.org/10. 2305/IUCN.CH.2016.13.en xiii + 97pp

16. European Commission (2015) Towards an EU Research and Innovation policy agenda for Nature-Based Solutions \& ReNaturing Cities. European Commission and Directorate-General for Research and Innovation, Brussels, Belgium. https://doi.org/10.2777/765301

17. Schönborn A, Junge R (2021) Redefining ecological engineering in the context of circular economy and sustainable development. Circular Economy and Sustainability. https://oi.org/10.1007/s43615-02100023-2

18. Mitsch W (1998) Ecological engineering - the 7-year itch. Ecol Eng 10(2):119-130

19. Daims H, Taylor MW, Wagner M (2006) Wastewater treatment: a model system for microbial ecology. Trends Biotechnol 24(11):483-489

20. Seviour R, Nielsen PH (2010) Microbial ecology of activated sludge. IWA publishing. 688pp. ISBN 13: 9781843390329

21. Ford AT, Barrueto M, Clevenger AP (2017) Road mitigation is a demographic filter for grizzly bears. Wildl Soc Bull 41(4):712-719

22. Simpson NO, Stewart KM, Schroeder C, Cox M, Huebner K, Wasley T (2016) Overpasses and underpasses: effectiveness of crossing structures for migratory ungulates. J Wildl Manag 80(8):1370-1137

23. Galatowitsch SM (2012) Restoration ecology. Sinauer Associates, Sunderland, Massachusetts

24. Townsend CR (2007) Ecological applications: toward a sustainable world. Wiley-Blackwell, 328pp. ISBN:978-1-405-13698

25. Carnot S (1824) Reflections on the motive power of fire and on machines fitted to develop that power. In: Mendoza E (ed) Translated by RH Thurston. Dover Publications, p 1960, 292pp

26. Savery T (1702) The miner's friend; or, an engine to raise water by fire. W. Clawes, Reprinted London, $p$ 1827

27. Gürsan C, de Gooyert V (2021) The systemic impact of a transition fuel: does natural gas help or hinder the energy transition? Renew Sust Energ Rev 138(C):110552

28. Queensland Government (2019a) Petroleum and coal seam gas. https://www.business.qld.gov.au/ industries/mining-energy-water/resources/petroleumenergy/outlook-statistics/petroleum-gas. (accessed Apr. 10, 2021)

29. Underschultz JR, Vink S, Garnett A (2018) Coal seam gas associated water production in Queensland: actual vs predicted. J Nat Gas Sci Eng 52:410-422. https://doi.org/10.1016/j.jngse.2018.02.010

30. Dale GT, Robb I, Halpin N, Macfarlane D, Rattray R (2013) Opportunities for integrated mine management to minimise risk and create value. In: Proceedings Water in Mining 2013. The Australasian Institute of Mining and Metallurgy, Melbourne, pp 227-234

31. Forum for the Future (2005) The five capitals. www.forumforthefuture.org/project/five-capitals/overview. (accessed Apr. 10, 2021) 
32. Dale GT (2015) Considerations and challenges in sustainable use of coal seam gas water for irrigated agriculture. Water J Aust Water Assoc 42(Supplement, 2015):18-23

33. Queensland Government (2019b) Petroleum and gas production and reserve statistics. https://www.data. qld.gov.au/dataset/petroleum-gas-production-andreserve-statistics. (accessed Apr. 10, 2021)

34. Hughes J, Thirgood JV (1982) Deforestation, erosion, and forest management in Ancient Greece and Rome. J For Hist 26(2):60-75. https://doi.org/10.2307/4004530

35. Huntley B, Daniell JRG, Allen JRM (1997) Scottish vegetation history: the highlands. Bot J Scotl 49(2): 163-175. https://doi.org/10.1080/03746609708684864

36. Mather AS, Fairbairn J (2000) From floods to reforestation: the forest transition in Switzerland. Environ Hist 6(4):399-421 (23)

37. O'Brien W (2014) Prehistoric copper mining in Europe: 5500-500 BC. Oxford University Press, 358pp. ISBN:9780199605651

38. European Commission (2008) Groundwater protection in Europe - the new groundwater directive consolidating the EU regulatory framework. Office for Official Publication of the European Communities, Luxemburg. https://doi.org/10.2779/84304

39. Busch K-F, Uhlmann D, Weise G (1989) Ingenieurökologie. VEB Gustav Fischer Verlag Jena; ISBN-13: 978-3334002179

40. Etnier C, Guterstam B (eds) (1991) Ecological engineering for wastewater treatment. Bokskogen, Gothenburg, Sweden

41. Thofelt L, Englund A (1996) Ecotechnics for a sustainable society. In: Proceedings from Ecotechnics 95 International Symposium on Ecological Engineering. Mid Sweden University, Frösön, Sweden. ISBN:9187908-03-4

42. Staudenmann J, Schönborn A, Etnier C (1996) Recycling the resource - ecological engieering for wastewater treatment, Enviornmental Research Forum, vols 5-6. Transtec Publications. ISBN:0-87849$741-2$

43. Carvalho PN, Arias CA, Brix H (2017) Constructed wetlands for water treatment: new developments. Water 2017(9):397. https://doi.org/10.3390/w9060397

44. Dotro G, Langergraber G, Molle P, Nivala J, Puigagut J, Stein O, von Sperling M (2017) Treatment Wetlands. Water Intell Online 16:9781780408774. https://doi.org/10.2166/9781780408774

45. Stefanakis AI (2019) The role of constructed wetlands as green infrastructure for sustainable urban water management. Sustainability 11(24):6981. https://doi.org/10.3390/su11246981

46. Stefanakis AI (2018) Constructed wetlands for industrial wastewater treatment, first edn. John Wiley \& Sons Ltd, Chichester, UK

47. Graber A, Junge R (2009) Aquaponic systems: nutrient recycling from fish wastewater by vegetable production. Desalination 246:147-156. https://doi.org/10.1016/j.desal.2008.03.048

48. Buehler D, Antenen N, Frei M, Koller C, Rousseau DPL, Schoenborn A, Junge R (2020) Towards water and energy self-sufficiency: a closed-loop, solardriven, low-tech laundry pilot facility (LaundReCycle) for the reuse of laundry wastewater. Circ Econ Sustain, Springer. In: Closed Cycles and the Circular Society : The Power of Ecological Engineering, Online, 2-4 September 2020

49. Zevenbergen C, Fu D, Pathirana A (2018) Transitioning to sponge cities: challenges and opportunities to address urban water problems in China. Water 10(9):1230. https://doi.org/10.3390/w10091230

50. European Commission (2013b) Building a green infrastructure for Europe European Union: Brussels, Belgium, 2013; ISBN 978-92-79-33428-3.

51. European Commission (2011) The EU biodiversity strategy to 2020. Publications Office of the European Union, Luxembourg, pp 1-27. https://doi.org/10.2779/39229

52. European Commission (2020) EU biodiversity strategy for 2030. Bringing nature back into our lives. https://ec.europa.eu/commission/presscorner/detail/en/QANDA_20_886

53. European Commission (2019) A European Green Deal. Striving to be the first climate-neutral continent. https://ec.europa.eu/info/strategy/priorities-2019-2024/european-green-deal_en. (accessed Apr. 10, 2021)

54. Kadlec RH (2019) Treatment marshes for runoff and polishing. $\bar{C}$ C Press, 1056pp. ISBN: 9781138322622

55. Kadlec RH, Knight RL (1996) Treatment wetlands. Lewis Publishers, Boca Raton, Florida

56. Kadlec R, Wallace S (2009) Treatment wetlands. CRC Press, Boca Raton, Florida

57. Cooke GD, Welch EB, Peterson SA, Nichols SA (2005) Restoration and management of lake and reservoirs, 3rd edn. Taylor \& Francis, New York, New York

58. McCutcheon SC, Schnoor JL (2004) In: McCutcheon SC, Schnoor JL (eds) Overview of Phytotransformation and Control of Wastes. Phytoremediation: Transformation and Control of Contaminants. John Wiley \& Sons, Inc, pp 1-58 
59. SFWMD (South Florida Water Management District) (2017) Harmful nutrients in the everglades now reduced by $90 \%$. https://www.sfwmd.gov/sites/default/files/documents/infographic_everglades_wq.pdf. (accessed Apr. 10, 2021)

60. Dierberg F, DeBusk TA, Jackson SD, Chimney MJ, Pietro K et al (2002) Submerged aquatic vegetationbased treatment wetlands for removing phosphorus from agricultural runoff: response to hydraulic and nutrient loading. Water Res 36(6):1409-1422

61. James TR, Chimney MJ, Sharfstein B, Engstrom DR, Schottler SP, East T, Jin K-R (2008) Hurricane effects on a shallow lake ecosystem, Lake Okeechobee, Florida (USA). Fundam Appl Limnol 172(4):273287

62. Chimney M (2019) Chapter 5B: performance and operation of the everglades stormwater treatment areas. South Florida Environmental Report, South Florida Water Management District West Palm Beach, pp 136

63. Groves D, Bonzanigo L, Syme J, Engle N, Rodriguez I (2019) Preparing for future droughts in Lima, Peru: enhancing Lima's drought management plan to meet future challenge. Retrieved from Washington D.C.: http://documents.worldbank.org/curated/en/827271557387444955/pdf/Preparing-for-Future-Droughts-inLima-Peru-Enhancing-Lima-s-Drought-Management-Plan-to-Meet-Future-Challenges.pdf. (accessed Apr. 10, 2021)

64. SENAMHI (National Weather Service and Hydrology of Peru) (2010) https://www.preventionweb.net/ organizations/12272. (accessed Apr. 10, 2021)

65. Hommes L, Boelens R (2017) Urbanizing rural waters: rural-urban water transfers and the reconfiguration of hydrosocial territories in Lima. Polit Geogr 57:71-80. https://doi.org/10.1016/j.polgeo.2016.12.002

66. Ioris A (2012) The geography of multiple scarcities: urban development and water problems in Lima, Peru. Geoforum 43(3):612-622. https://doi.org/10.1016/j.geoforum.2011.12.005

67. SUNASS (Superintendencia Nacional de Servicios de Saneamiento) (2017) Directiva de Mecanismos de Retribución por Servicios Ecosistémicos Hídricos - MRSE Hídricos y modifican disposiciones aprobadas mediante las RR. Nº 009, 003 y 011-2007-SUNASS-CD. Retrieved from https://www.academia.edu/ 35725120/Resolucion_045_2017_sunass. (accessed Apr. 10, 2021)

68. Apaza D, Arroyo R, Alencastre A (2006) Las Amunas de Huarochirí: Recarga de Acuíferos en los Andes. Gestión Social del Agua y Ambiente en Cuencas (GSAAC). Embajada Real de los Países Bajos y IICAPerú. https://hidraulicainca.files.wordpress.com/2011/07/libro-amunas-gsaac.pdf. 9pp. (accessed Apr. 10, 2021)

69. Ochoa-Tocachi B, Bardales J, Mao F, De Bievre B, Antiporta J, Zulkafli Z, Buytaert W (2019) Potential contributions of pre-Inca infiltration infrastructure to Andean water security. Nature Sustainability 2(7): 584-593. https://doi.org/10.1038/s41893-019-0307-1 https://www.researchgate.net/publication/ 333986846_Potential_contributions_of_pre-Inca_infiltration_infrastructure_to_Andean_water_security (accessed Apr. 10, 20리)

70. Hopkins LG (2016) Dung beetle activity in the Northern Rivers region of New South Wales. Southern Cross University- School of Environment, Science and Engineering, Lismore, NSW 45pp

71. Gammie G, De Bievre B (2015) Assessing green interventions for the water supply of Lima, Peru. Retrieved from https://www.cbd.int/financial/doc/perulimawater.pdf. (accessed Apr. 10, 2021)

72. Observatorio del Agua Chillón Rímac y Lurín (2019) Proyectos de Infraestructura Natural (a julio de 2019). Retrieved from http://observatoriochirilu.ana.gob.pe/sites/default/files/Proyectos\%20de $\%$ 20Infraestructura\%20Natural\%20(a\%20julio\%202019).pdf. (accessed Apr. 10, 2021)

73. Ministerio de Economía y Finanzas (MEF) (2017) El nuevo sistema de inversión pública. Retrieved from https://www.mef.gob.pe/contenidos/inv_publica/docs/invierte/INVIERTE.PE.pdf. (accessed Apr. 10, 2021)

74. O’Dwyer E, Wang H, Wang A, Shah N, Guo M (2018) In: Friedl A, Klemeš JJ, Radl S et al (eds) Optimisation of wastewater treatment and recovery solutions in industrial parks, vol 43. Computer Aided Chemical Engineering, pp 1407-1412

75. Zhang Y, Du J, Xing B, Geller G, Rustige H (2015) Experiences with hybrid constructed wetland and pond system for polytypic wastewater treatment. Water Pract Technol 10:771-776. https://doi.org/10. 2166/wpt.2015.095

76. Weyer VD, de Waal A, Lechner AM, Unger CJ, O'Connor TG, Baumgartl T, Schulze R, Truter WF (2019) Quantifying rehabilitation risks for surface-strip coal mines using a soil compaction Bayesian network in South Africa and Australia: to demonstrate the R2AIN Framework. Integr Environ Assess Manag 15:190-208

77. Australian Government, Department of Industry Tourism and Resources (2006) Mine rehabilitation handbook: Leading Practice Sustainable Development Program for the mining industry. Australian Government Department of Industry Tourism and Resources, Canberra, (AU) p 67 
78. Australian Government, Department of Industry Innovation \& Science, Department of Foreign Affairs \& Trade (2016) Mine rehabilitation: leading practice sustainable development program for the mining industry. Leading Practice Sustainability Program for the Mining Industry, Canberra, 77pp

79. Chamber of Mines of South Africa (1981) Guidelines for the rehabilitation of land disturbed by surface coal mining in South Africa. Chamber of Mines of South Africa, Johannesburg, (ZA) p 96

80. Chamber of Mines of South Africa (2007) Guidelines for the rehabilitation of mined land. Chamber of Mines of South Africa, Johannesburg, (ZA), p 167

81. Land Rehabilitation Society of Southern Africa, Coaltech, Minerals Council of South Africa (2018) Land rehabilitation guidelines for surface coal mines. Land Rehabilitation Society of Southern Africa, Coaltech, Minerals Council of South Africa, Johannesurg, ZA, p 199

82. Minerals Council of Australia (1998) Mine rehabilitation handbook. Minerals Council of Australia, Kingston, (AU), p 112

83. Hamza MA, Anderson WK (2005) Soil compaction in cropping systems: a review of the nature, causes and possible solutions. Soil Tillage Res 82:121-145

84. Lal R (2009) Soils and food sufficiency. A review. Agron Sustain Dev 29:113-133

85. Mueller L, Schindler U, Mirschel W, Shepherd TG, Ball BC, Helming K, Rogasik J, Eulenstein F, Wiggering H (2010) Assessing the productivity function of soils. A review. Agron Sustain Dev 30:601614

86. Rethman NFG (2006) A review of causes, symptoms, prevention and alleviation of soil compaction on mined land. Coaltech 2020, Johannesburg, (ZA). https://doi.org/10.1016/B978-0-444-64235-6.50246-1

87. Reynolds K, Kruger R, Rethman N, Truter W (2002) The production of an artificial soil from sewage sludge and fly-ash and the subsequent evaluation of growth enhancement, heavy metal translocation and leaching potential. Water SA 29:73-77

88. Truter, WF, Rethman NFG (2003) Reclaiming mine lands in grassland areas with industrial and urban byproducts. Afr J Range Forage Sci 20(2):234-238

89. Abraha AB, Tesfamariam EH, Truter WF (2019) Can a blend of amendments be an important component of a rehabilitation strategy for surface coal mined soils? Sustainability 11:4297

90. Dabrowski J, Venter G, Truter WF, Scholtz CH (2019) Dung beetles can tunnel into highly compacted soils from reclaimed mined sites in eMalahleni, South Africa. Appl Soil Ecol 134:116-119

91. Badenhorst J, Dabrowski J, Scholtz CH, Truter WF (2018) Dung beetle activity improves herbaceous plant growth and soil properties on confinements simulating reclaimed mined land in South Africa. Appl Soil Ecol 132:53-59

92. WRS (World Resources Institute) (2019) Available online: https://www.wri.org/aqueduct (accessed on 15 November 2020)

93. Stefanakis AI (2020) Constructed wetlands for sustainable wastewater treatment in hot and arid climates: opportunities, challenges and case studies in the Middle East. Water 12(6):1665. https://doi.org/10.3390/ w12061665

94. Aditya R. (2016) Produced water treatment market by application (onshore and offshore), by treatment types (physical, chemical, membrane and others), and by geography. Global Trends \& Forecast to 2019. Markets and Markets Report. (accessed Apr. 10, 2021)

95. Stefanakis AI, Prigent S, Breuer R (2018a) Integrated produced water management in a desert oilfield using wetland technology and innovative reuse practices. In: Stefanakis AI (ed) Constructed Wetlands for industrial wastewater treatment. John Wiley \& Sons Ltd, Chichester, UK, pp 25-42

96. Echchelh A, Hess T, Sakrabani R, Prigent S, Stefanakis AI (2021) Towards agro-environmentally sustainable irrigation with treated produced water in hyper-arid environments. Agric Water Manag 243: 106449

97. Stefanakis AI, Charalampopoulos I, Psomiadis E, Prigent S (2018b) The thermal regime of a large constructed wetland in the desert environment. In: 16th IWA International Conference on Wetland Systems for Water Pollution Control, Valencia, Spain September 30 - October 1

98. ESA (Ecological Society of America) (2021) What is ecology? https://www.esa.org/about/what-doesecology-have-to-do-with-me/. (accessed Apr. 10, 2021)

99. Rowe JS (1961) The level-of-integration concept in ecology. Ecology 42:420-427

100. Mengak MT, Rutledge HE, McDonald B (2009) Ecological principles - a unifying theme in environmental education. J Ext 47(5):5RIB6 8pp

101. Dale VH, Brown S, Haeuber RA, Hobbs NT, Huntly N, Naiman RJ, Riebsame WE, Turner MG, Valone TJ (2000) Ecological principles and guidelines for managing the use of land. Ecol Appl 10(3):639-670

102. MacMahon JA, Phillips DL, Robinson JV, Schimpf DJ (1978) Levels of biological organization: an organism-centered approach. BioScience 28:700-704 
103. ABET (2020) Criteria for Accrediting Engineering Programs, 2020 - 2021. https://www.abet.org/ accreditation/accreditation-criteria/criteria-for-accreditingengineering-programs-2020-2021/. (accessed Apr. 10, 2021)

104. Dark M, Ngambeki I, Depew D, Chong R (2014) Social engagement by the engineer. In: Coyle ED, Simmons RA (eds) Understanding the global energy crisis. Purdue University Press Chapter 3. (2014): https://www.jstor.org/stable/j.ctt6wq56p.8. (accessed Apr. 10, 2021)

105. IEA (Institution of Engineers, Australia) (2020) What is engineering? https://www.engineersaustralia.org. au/For-Students-And-Educators/Engineering-Careers/What-Is-Engineering. (accessed Apr. 10, 2021)

106. NAE (National Academy of Engineering) (2004) The Engineer of 2020: Visions of Engineering in the New Century. National Academy Press, 2004. 118pp. ISBN 978-0-309-09162-6. https://doi.org/10.17226/ 10999. http://www.nap.edu/openbook.php?isbn=0309091624 (accessed Apr. 10, 2021)

107. Allen TFH, Giampietro M, Little AM (2003) Distinguishing ecological engineering from environmental engineering. Ecol Eng 20:389-407

108. Odum HT (1971) Environment, Power, and Society. John Wiley \& Sons, Inc., New York

109. Mitsch W (2012) What is ecological engineering? Ecol Eng 45(2012):5-12

110. WCED (World Commission on Environment and Development) (1987) Our common future. Oxford University Press, Oxford, United Kingdom

111. Roser M (2019) The short history of global living conditions and why it matters that we know it. https:// ourworldindata.org/a-history-of-global-livingconditions-in-5-charts

112. Matlock MD, Osborn GS, Hession WC, Kenimer AL, Storm DE (2001) Ecological engineering: a rationale for standardized curriculum and professional certification in the United States. Ecol Eng 17: 403-409

113. ACCSR (Australian Centre for Corporate Social Responsibility) (2011) The state of CSR in Australia. Annual Review 2010/11. Summary Report. www.accsr.com.au. 16pp. (accessed Apr. 10, 2021)

114. Maciulyte E, Durieux E (2020) Public procurement of nature-based solutions Addressing barriers to the procurement of urban NBS: Case studies and recommendations. Report by the European CommissionDirectorate-General for Research and Innovation. 48pp. https://op.europa.eu/en/publication-detail/ publication/d75b2354-11bc-11eb-9a54-01aa75ed71a1/language-en/format-PDF/source-166334197 (accessed Apr. 10, 2021)

115. National Research Council (NRC) (2011) Sustainability and the U.S. EPA. The National Academies Press, Washington, DC. https://doi.org/10.17226/13152

116. IUCN (International Union for Conservation of Nature) (1980) World conservation strategy. Living Resource Conservation for Sustainable Development. Gland, Switzerland https://portals.iucn.org/library/ efiles/documents/WCS-004.pdf

117. GOWA (Government of Western Australia) (2021) The role of the EPA. https://www.epa.wa.gov.au/roleepa. (accessed Apr. 10, 2021)

118. UNCED (United Nations Conference on Environment and Development) (1992a) Agenda 21. United Nations Conference on Environment and Development, Rio de Janeiro, Brazil http://www. cuttingthroughthematrix.com/articles/Agenda21.pdf. (accessed Apr. 10, 2021)

119. Marsh GP (1864) Man and nature; or, physical geography as modified by human action. Belknap Press of Harvard University Press, Cambridge, MA, 568pp

120. Meadows DH, Randers J, Meadows D (1972) The limits to growth; a report for the Club of Rome's project on the predicament of mankind. Universe Books, New York, 368pp

121. Elkington, J (2018) 25 years ago i coined the phrase "Triple Bottom Line." Here's why it's time to rethink it. Harvard Business Review, 25 June 2018. https:/hbr.org/2018/06/25-years-ago-i-coined-the-phrasetriple-bottom-line-heres-why-im-giving-up-on-it. (accessed Apr. 10, 2021)

122. UNCED (United Nations Conference on Environment and Development) (1992b) Report of the United Nations Conference on Environment and Development, Rio de Janeiro, 3-14 June 1992, Annex I. Rio Declaration on Environment and Development. A/CONF.151/26 (Vol. I). United Nations General Assembly: https://www.un.org/esa/dsd/agenda21/Agenda\%2021.pdf. (accessed Apr. 10, 2021)

123. Millennium Ecosystem Assessment (MEA) (2005) Ecosystems and human well-being: synthesis. Island Press. isbn:Washington, DC, 1-59726-040-1

124. Roetman PEJ, Daniels CB (2011) Creating sustainable communities in a changing world. Crawford House Publishing, Adelaide, p 262

125. Raworth K (2017) Doughnut economics: seven ways to think like a 21st-century economist. Chelsea Green Publishing. 320pp, Vermont, USA. ISBN:13: 978-1603586740

126. Schandl H, Hatfield-Dodds S, Wiedmann T, Geschke A, Cai Y, West J, Newth D, Baynes T, Lenzen M, Owen A (2016) Decoupling global environmental pressure and economic growth:scenarios for energy use, materials use and carbon emissions. J Clean Prod 132:45-56 
127. Business and Sustainable Development Commission (2017) Better business, better, world. In: The report of the Business \& Sustainable Development Commission. Business and Sustainable Development Commission. London ECY 5EJ 122pp

128. Costanza R (ed) (1991) Ecological economics: the science and management of sustainability. Columbia University Press, New York, p 1991

129. Etnier C, Guterstam B (eds) (1997) Ecological engineering for wastewater treatment, Second edn. CRC Press, 47pp

130. Yan J, Zhang Y (1992) Ecological techniques and their application with some case studies in China. Ecol Eng 1:261-285

131. Yan J, Zhang Y, Wu X (1993) Advances of ecological engineering in China. Ecol Eng 2:193-215

\section{Affiliations}

Glenn Dale ${ }^{1,2} \cdot$ Gabriela Dotro $^{3} \cdot$ Puneet Srivastava $^{4} \cdot$ David Austin $^{5} \cdot$ Stacy Hutchinson $^{6}$ • Peter Head ${ }^{7}$ - Ashantha Goonetilleke ${ }^{8}$ - Alexandros Stefanakis $^{9} \cdot$ Ranka Junge $^{10}$. José A. Fernández L. ${ }^{11} \cdot$ Vanessa Weyer $^{12} \cdot$ Wayne Truter $^{12} \cdot$ Devi Bühler $^{10}$. John Bennett ${ }^{2}$ Hongbo Liu ${ }^{13} \cdot$ Zifu Li $^{14}$ • Jianqiang Du ${ }^{15,16} \cdot$ Petra Schneider $^{17}$ • Jochen Hack $^{18}$ - Andreas Schönborn ${ }^{10}$

\footnotetext{
$1 \quad$ Verterra Ecological Engineering, Brisbane, Australia

2 University of Southern Queensland, Toowoomba, Australia

3 Cranfield University, Cranfield, UK

4 University of Maryland, College Park, Maryland, USA

5 Jacobs, Mendota Heights, Minnesota, USA

6 Kansas State University, Kansas, USA

7 Ecological Sequestration Trust, London, UK

8 Queensland University of Technology, Brisbane, Australia

9 School of Environmental Engineering, Technical University of Crete, Chania, Greece

10 Zurich University of Applied Sciences, Wädenswil, Switzerland

11 Griffith University International Water Centre, Brisbane, Australia

12 University of Pretoria, Pretoria, South Africa

13 University of Shanghai for Science and Technology, Shanghai, China

14 University of Science and Technology Beijing, Beijing, China

15 Suzhou DeHua Ecological Technology Corp., Suzhou, China

16 Ingenieurökologische Vereinigung, Augsburg, Germany

17 Magdeburg-Stendal University of Applied Sciences, Magdeburg, Germany

18 Technical University Darmstadt, Darmstadt, Germany
} 